\title{
CARTAS DE LUIS G. URBINA A ALFONSO REYES
}

Casi dos generaciones separaban en edad a Luis G. Urbina y Alfonso Reyes. El primero nació en 1864 y el segundo en 1889: veinticinco años de diferencia. Curiosamente, es el mismo número de años que transcurre entre la muerte de Luis G. Urbina (18 de noviembre de 1934) y la de Alfonso Reyes (29 de diciembre de 1959). Ambos vivieron setenta años y mantuvieron una larga amistad, nunca perturbada, aunque la vida los llevó por rumbos distintos. Esta amistad, iniciada en 1905 o 1906, se prolongaría hasta la muerte de Luis G. Urbina en Madrid, aunque para entonces Reyes ya llevaba diez años fuera. de España.

Eran muy distintos: por su edad, por la condición socioeconómica de sus orígenes, por su formación y sensibilidad, por sus intereses intelectuales. Uno miraba al pasado, el otro al futuro. Sobre el trasfondo de las letras y la poesía, la amistad de Reyes y Urbina fue una relación humana sostenida en el afecto y el respeto a los valores fundamentales de la existencia: la amistad, la generosidad, la rectitud. Ambos fueron por igual ajenos a los disturbios de la codicia, la ambición o la maledicencia. Lo que Reyes afirmó de Urbina vale para ambos: "Su talento era parte de su bondad"'.

La amistad arranca de 1906, año de fundación de la revista Savia moderna, si bien uno ya sabía del otro desde mucho antes. Según el testimonio de Urbina, conoció a Reyes en 1899 o 1900, en un teatro de la ciudad de México. Tenía Reyes diez años de edad e iba de la mano de su padre. En el entreacto, el general Reyes saludó a Carlos Díaz Dufoo, que acompañaba en esa oca-

1 “'Recordación de Urbina", en Pasado inmediato, AROC, t. 12, p. 272. 
sión a Urbina y le presentó a su hijo (Alfonso Reyes había leído los Cuentos nerviosos de Dufoo). - Le ha gustado el libro de usteddijo el general Reyes, y comenta Urbina que la cara infantil de Alfonso Reyes "se iluminó de pronto, con luz de entusiasmo. No era propia de su edad la llama interior que le encendía los ojos cándidos. Se adivinaba en él a un lector ardiente"'2. Es posible que el niño haya retenido la imagen de ese encuentro con Urbina (entonces con 36 años de edad), figura consagrada ya con un libro de poemas y una amplia actividad periodística.

Alfonso Reyes regresó a Monterrey para iniciar sus estudios de bachillerato en el Colegio Civil del Estado y en 1905 se trasladó a la ciudad de México para concluirlos en la Escuela Nacional Preparatoria. Era la época en que empezaba a gestarse el movimiento cultural que culminaría con las actividades del Ateneo de la Juventud antes del estallido de la Revolución. Reyes ha contado que a su llegada a la ciudad de México, se introducía a la cátedra de Luis G. Urbina en la Escuela Nacional Preparatoria, "por el gusto de oírle leer en voz alta algunos pasajes del Sombrero de tres picos o alguna cosilla de poesía" 3 . Dos hermanos mayores reconoció Alfonso Reyes entre los escritores que frecuentaban él y los miembros de su generación: Enrique González Martínez y Luis G. Urbina. Este último se acercó al grupo del Ateneo de la Juventud; y cuando esta nueva generación de escritores empezó a reunirse, "aquel poeta de primera fila, aquel periodista cotizado, aquel maestro, instintivamente se acercó a nosotros, entró en nuestras inquietudes, y aun abrió de nuevo los libros en nuestra compañía. Poco después, hasta nos tuteábamos..."

En 1913, el 9 de febrero se inicia la "Decena trágica" y ese día el general Reyes muere acribillado ante las puertas del Palacio Nacional. Un mes y días después de este acontecimiento, el 16 de marzo, Urbina escribe unas líneas a Alfonso Reyes:

Alfonso muy querido: / Estaré puntualmente donde, por encargo de Ezequiel, me citas. Ya sabía algo de lo que me anuncias en tu recado. Siento deveras no haber podido darte hoy el abrazo dominical, y ver en tus ojos y sentir en tus palabras tu clara, dulce y pen-

${ }^{2}$ Luis G. URBina, "Madrid se despide de Alfonso Reyes. Dibujos en un menú", Páginas sobre Alfonso Reyes, 1911-1945, Universidad de Nuevo León, Monterrey, 1955, t. 1, p. 49. El texto de Urbina se publicó en El Universal, México, D.F., el 11 de mayo de 1924.

3 "Recordación de Urbina", p. 273.

${ }^{4}$ Ibid. 
sativaijuventud. Celebraré que tu mal de garganta no te impida cantar mañana un aleluya - fújate: no una aleluya - al advenimiento de un proyecto de estudios serios./Muy tuyo/ Luis.

Es la primera carta de Urbina a Reyes en el archivo de éste, y por su tono y contenido se deja ver la relación de amistad que ya unía a ambos escritores a pesar de la diferencia de edad. Para esa fecha, ya Luis G. Urbina había sido nombrado director de la Biblioteca Nacional (26 de febrero) y es probable que en el recado de Reyes, a que hace mención Urbina, aquél le informara de su posible designación como segundo secretario de la Legación de México en Francia. Cuatro meses más tarde, el 16 de julio, Alfonso Reyes recibe su título de abogado y un día después es designado segundo secretario en la Legación mexicana en $\mathbf{P a -}$ rís; se embarca el 12 de agosto para Europa, donde permanecería once años, hasta 1924.

Luis G. Urbina duró dieciocho meses en el cargo de director de la Biblioteca Nacional (había tomado posesión el primero de marzo); termina su función el 28 de agosto de 1914, al caer Victoriano Huerta. En esas mismas fechas y por la misma razón, el personal de la Legación de México en Francia queda despedido. Alfonso Reyes viaja a España y se instala en Madrid, adonde llega el 2 de octubre de ese año de 1914, sin empleo y sin recursos. Desde México, Urbina le escribe el 20 de octubre y el tono inicial de la carta se explica por la circunstancia personal en que se encontraban ambos:

Oct. 20,1914

Mi querido Alfonsito:

No hablemos ni de tu vida ni de la mía por no hablar de cosas tristes. Me figuro tus inquietudes y tus penas. Te figurarás las mías. Añadamos un cincuenta por ciento a lo que nos figuramos y nos habremos acercado a lo cierto. Pero por fortuna, nuestros valores efectivos conservan su integridad y eso ya es algo, como decía el buen Andersen. Yo he quedado de esta prueba un sentimental cristalino: frágil y sonoro al más ligero aire espiritual. Soy un licenciado vidriera del corazón. Te recuerdo con una suave emoción de dolor, un poco a lo romántico, como, cuando tenía quince años, me acordaba de mis hermanitos. Y te veo chiquitín, guapillo, con tu sonrisa cariñosa y tus ojos infantiles, andar como el héroe del humorista, en busca de una posición; sólo que la tuya no es social —no quieres tal cosa - sino intelectual. Buscas tu rincón escondido y claro, en 
el que poder estudiar, pensar y amar. Lo encontrarás. Tienes talento y fe. Y te será más grato cuanto más trabajo te cueste hallarlo. Todo tu ser moral, en plena asunción, va a salir vigorizado por efecto de esta gimnasia de la voluntad que estás haciendo. Yo sé bien lo que vales y confío ciegamente en ti. Reconozco que eres un tranquilo consciente, un domador de ímpetus y arrebatos. Y espero verte siempre así.

De mí te sé decir que lo que me ha salvado mi mundo interior intacto, es la serenidad. Ahora mismo que te escribo entre cuatro paredes desnudas, sobre las tablas de un estante vacío, sigo tan melancólicamente contento como cuando estaba yo rodeado de libros, de amigos y de mi viejo bienestar burgués. Todo se ha perdido fuera de mí, pero dentro de mí nada se ha alterado. Y peso, día por día, mi sentencia kempisteana: Ama tu cruz...

Ya ves, he tenido paciencia para coleccionar mis últimos versos, y mansedumbre para darlos a la estampa. Te los mando. El libro resultó feo y con apariencia de pequeño - no obstante que contiene igual o mayor material que otros míos. Pero es que aquí toda adquisición [sic] editorial se dificulta mucho: el papel, la imprenta, el cajista, todo. A pesar de ello, estoy preparando mis cuatro libros de prosa; mi selección de artículos y trabajos literarios. Va tan adelantada la cosa que antes de que termine noviembre habré concluido. Entonces me dedicaré a concluir una novela empezada y a comenzar mis memorias. Porque no quiero dejar de decir mi palabra, la que ha de revelar cómo un hombre, más o menos corriente, vio la vida de los demás en relación con la suya propia. Quizá tengan algún interés para los futuros curiosos de psiquis las confidencias de un sencillo hombre de letras que se agita en un medio reacio y casi hostil a la cultura. ¿Qué te parece? Todo lo haré, todo lo escribiré en los intervalos que me deja la necesaria pesca del pan que está siendo para mí fatigosa, pero que, por hoy, me permite encerrarme largas horas en mi casa. Tengo horror a la calle; una cnfermedad que tal vez pudiera llamarse viafobia. Dime con tu fraternal franqueza los defectos graves de mi libro último. Infórmame de cuanto hayas producido y mándamelo, si ouedes. Y también infórmame de ti, de tu aguilucho. Y de dónde anda Amado Nervo, a quien tengo que escribir largo, y Pancho Icaza, a quien debo saludos y pláticas, y Ángel Zárraga, y Carfitos Lozano... . Y basta de informaciones. Si me contestas, me darás mi consuelo. Te quiere con todo su corazón tu hermano

Esta carta de Luis G. Urbina a Reyes debió significar el apoyo moral que éste necesitaba para enfrentar su difícil situación en Madrid, sobre la que el mismo Reyes dejó un amplio testimo- 
nio en su Historia documental de mis libros, IV. El libro al que se refiere Urbina, y del que espera los comentarios de su amigo es Lámparas en agonía, publicado con pie editorial de la Viuda de Ch. Bouret y prólogo de Enrique González Martínez. Las memorias a que hace referencia nunca las escribió, como se explica al final de este trabajo. De los cuatro libros con selección de artículos y trabajos literarios, se publicó en México en 1915 Cuentos vividos y crónicas soñadas, editado por Eusebio Gómez de la Puente. En este mismo libro se anuncian, en prensa, Los gestos de la carátula, primera serie, y en preparación la segunda serie, más Psiquis enferma y Hombres y libros. Estos dos últimos se publicaron en México por El libro francés, el año de 1923. Del primero, ninguna de las dos series forma parte de la bibliografía de Urbina.

Las cosas marchan mal para Urbina en México. Ese mismo año de 1914 fue apresado durante tres días; se vive con dificultades en la ciudad, hay persecuciones, y finalmente deja la capital el primero de marzo de 1915 para dirigirse a La Habana, en compañía del músico y compositor Manuel M. Ponce y el violinista Pedro Valdés Fraga. Su permanencia en la capital de Cuba es de catorce meses, como colaborador de El Heraldo de Cuba. Pero recién llegado a La Habana, Urbina escribe a Reyes el 28 de mayo de 1915 una larga carta, donde explica la difícil situación que ha vivido en la ciudad de México y las razones que lo orillaron a emigrar. El documento es sin duda un testimonio de primera importancia para conocer las circunstancias prevalecientes en la capital de la República en 1914 y 1915, años iniciales de la Convención y de la presidencia provisional del general Eulalio Gutiérrez:

Alfonsito mío:

Muy retardada recibo tu tarjeta postal. Para llegar aquí, ya te imaginarás qué dificultades, qué trabajos, qué catástrofes. Frente a mí la suerte me está borrando la vida, como un chiquillo malcriado borra la caligrafía laboriosa de una pizarra. Mi vieja plana se está desvaneciendo. Y yo lo veo con interés, con resignación y con tristeza. Es cosa curiosa ésta de asistir a los propios derrumbamientos. ¿Parciales? ¿Totales? Acaso nada más incidentales. ¡ Ojalá que el alarife que llevamos dentro se apresure a levantar lo destruido. Materiales hay; pero mi albañil parece un poco cansado. Lo vigilaré. Lo malo es que ya comienza a no entusiasmarle el jornal de verdad y de ilusión que le ofrezco. Los ancianos no tienen en qué gastar sus ahorros y por eso se apoltronan. Y ya mi espíritu siente fatiga de vejez. Veremos. 
Hace ocho meses, en octubre del año pasado, te escribí una carta de abuelo, muy larga, muy llena de apotegmas para uso de la niñez incauta; con la carta, te envié mi libro Lámparas en agonía. Castro Antonio*, que fue el encargado del tránsito postal, me aseguró que te mandaría carta y libro. ¿Los recibiste?

Te me has escondido tanto tiempo, como duende travieso, que nada sé sino que vives, que sufres, que trabajas. En malas andanzas sigue el mundo, Alfonso. Malas y un poco inútiles. Todo quedará peor para volver todo a lo mismo.

Ahora, te abreviaré el cuento. La cultura en México ha caído con tanto estrépito que he quedado poco menos que sordo: muy tardo de oído. Apenas percibo las voces de nuestros amigos y camaradas. De cuando en cuando veía pasar, durante mis escapatorias a la calle (he estado escondido, preso, detenido, fugitivo, etc., etc.), a Julio Torri del brazo de Antonio Castro, y a Manuel Toussaint de la mano de Alberto Vázquez del Mercado. Iban rumbo a la Librería General. Los veía pero no los oía. Ellos están mudos como yo sordo. Y luego... ¡ hacen tanto ruido sables, fusiles, corceles y cañones! ¡Desconcierta de veras este concertante militar! El pretorianismo está echando mucho tejido adiposo. Ya ni le vienen los pantalones de Don Venustiano ni las chaparreras de Villa. Aquella barriga tragona crece, crece. ¿Qué bien que se harta el ogro! La cosa, sin embargo, no tiene ya más remedio que apresurarla. Cuanto antes, mejor. Para ese envenenamiento no quedan ya sino los recursos terapéuticos de los sucesos revolucionarios. Lavar la sangre en circulación y adelante con los faroles. Por desgracia no hay hombres químicamente puros ni pueblos completamente esterilizados. Los tontos, los locos y los perversos que se metieron en la aventura de redimir sin educar y de libertar sin reprimir, pudieron hacer muchas cosas: heroicidades, dinero, buenas y malas acciones; lo que no llegaron ni llegarán a hacer es Gobierno. Lo hará la Casa Blanca y nada más. Lo hará sojuzgándonos y humillándonos, riéndose un poco, para adentro, de nuestra tragedia de monos. ¡Y dizque estábamos salvados!

Te diré: fuera de mi país, suspirando a plenos pulmones, he creído decoroso, pertinente, sano y honrado defender la revolución. En primer lugar, porque bajo la escoria de sangre, corre el anhelo humano de bienestar y de justicia. Y de cuando en cuando la corriente subterránea rompe la costra de lodo, y suelta un chorro nítido de cristal. Se chapotea en fango, pero cuando podemos beneficiar el fierro vemos que, por fragmentos, tiene ley de oro. Esta cosa abstrusa y monstruosa que se llama pueblo posee una virtualidad interesantísima; su egoísmo muestra aspectos sublimes. Sin embargo,

* Antonio Castro Leal. 
los que juegan con él lo prostituyen. La degradación colectiva va rumbo a la caverna. ¿'Te parezco demasiado incongruente? Es que estoy escribiendo lo que pienso en desorden, en mi cuarto de casa de huéspedes, con un calor que me derrite los sesos y una sofocación de cuarenta caballos.

Pues te decía. Los amigos que no están escondidos están mudos, y los que ni una ni otra cosa están, van para locos que vuelan. Enrique González Martínez no ha podido salir de su casa. Pobre como Job, se está comiendo sus uñas y sus libros. Me despedí de él cuando me propuse salir de México en busca de pan para los míos que ya ladran. El pan en mi casa había desaparecido y la vida pasaba unas congojas que no son para contarse. Va un ejemplo, tomado al acaso en la memoria. Una tarde de fríos de febrero, paseábamos Antonio Caso y yo por la Alameda de Santa María (¿te acuerdas?). Antonio acababa de ser aclamado, que no nombrado, Director de la Preparatoria. Hablábamos de programas de literatura. Estábamos tranquilamente departiendo bajo las ramas de Academus. De repente seis polizontes nos rodearon: con lujo de aparato y atrez$z o$ nos llevaron a la comisaría; nos soltaron luego; nos reaprehendieron a las pocas horas... y no te contaría yo esto si por una chiripa de la Providencia (no te rías) no sale a media noche del poder, un generalote energúmeno, de esos que en todo idiota con jaquet ven un científico. La cosa no es para salir a tomar chocolate. Desde entonces no veo a Antonio. ¡Pobrecillo! Se metió como los topos, debajo de la tierra. Todo ello tiene su explicación; se dice que se perseguía a los amigos de Pepe Vasconcelos. ¡Figúrate!

Bueno; tenté, antes de salir de mi casa, todos los caminos; edité libros, vendí chácharas, anduve la ceca y la meca. . . Nada. Con profunda pena, repartí a mi familia, muchacha por aquí, muchacha por allá, acullá la vieja, al otro lado la chiquilla para que no pesaran grandemente sobre los que les dieron hospitalidad y salí. Aquí me tienes. Necesito vivir para esas pobres criaturas, vivir y trabajar. Vine a La Habana de saltimbanqui literario. Mi inspiración vive la danza del vientre, en conciertos y veladas con Ponce y con Valdés Fraga. He escrito muchos versos, muchos artículos, de crítica, de política, de variedades; para darme a conocer como gente de letras y como laborioso. No cometo ninguna otra mala acción. No doy a ninguno sablazos. Me como mi amargura. Me bebo mi sudor. Y aquí estoy frente a ese monstruo de cartón que se llama la suerte. Acabo de dar en la Sociedad de Conferencias (Academia de letras y ciencias) una clase sobre lírica mexicana. Como carezco de libros de consulta (no me traje más que lo puesto), hice uso de la memoria y presenté un trabajo vivido. Llegué hasta Altamirano. En una segunda conferencia hablaré de Don Justo para acá. Pronto verás eso. A ver qué te parece. Ando en busca de labor literaria 
en la prensa. Aquí las literaturas son absolutamente inapreciadas, despreciadas mejor dicho. Si no encuentro puesto en esta prensa sui generis (ya te contaré) solicitaré oficios más bajos: mesero, vendedor de periódicos, repartidor de leche, o más bajo aún: barrendero, limpiabotas. . La existencia puede llevarme a la caricatura grotesca. Mi sonrisa interior, un poco mojada en lágrimas, no me abandonará. Confío en ella.

Aquí tienes, viejecito, el telón de fondo de mi vivir. Está pintado con brocha gorda. Pero como lo ves de lejos quizá te produzca efecto. Enséñale esta carta a Martín Guzmán. Para él es también. Dile que no olvido el cariño de ustedes y que lo traigo colgado al cuello como reliquia de beata. Abraza mucho, por mi cuenta, al Chato Acevedo, dile que aquí, en la misma casa de huéspedes ("Martínez House", Prado 104) donde yo resido vive también Chema Lozano; saluda cariñosamente a Rivera. Háblame de todo y de todos. Escríbeme pronto. Tus cartas me harán un inmenso bien. Lo mismo las de Martín.

No olviden a su amigo el viejecito.

De esta carta se desprende que Alfonso Reyes no contestó a Urbina la anterior, lo cual es explicable, pues se encontraba en aquel periodo heroico en el que se sostenía con su pluma "en pobreza y libertad"'. El mismo Reyes ha contado ya que los primeros textos de Cartones de Madrid, escritos al comienzo de la estancia madrileña, se publicaron casi todos a partir del 11 de febrero de 1915, en El Heraldo de Cuba, el periódico de La Habana en el que escribía Urbina, pero quien intervino para que se recibieran las colaboraciones del mexicano en Madrid fue Pedro Henríquez Ureña. De 1914 y 1915 son Cartones de Madrid y Visión de Anáhuac, aunque no se publicaron hasta 1917.

El 3 de mayo de 1916 se embarca Luis G. Urbina rumbo a España, adonde va como corresponsal de El Heraldo de Cuba, y previa estancia de dos meses en Barcelona llega a Madrid en pleno verano. Lo reciben en la Estación del Norte Amado Nervo y Alfredo Gómez de la Vega. Tenía entonces el poeta 52 años y los 18 restantes los vivió en Madrid, viajando a México en 1917, 1921 y 1925.

Seis años después de la muerte de Urbina, Reyes escribió un texto con recuerdos del poeta - páginas lamentablemente breves, dedicadas a los años previos a la Revolución, pero que muy poco dicen de la etapa de Madrid, apenas un párrafo. Para rescatar algo de aquellos años, nos quedan los textos periodísticos del mis- 
mo Urbina y sus cartas dirigidas a Reyes, cuidadosamente guardadas por éste. Las de Reyes a Urbina, por desgracia, están perdidas. Al final del trabajo, como ya se dijo antes, volveremos sobre esto. La correspondencia de Luis G. Urbina a Alfonso Reyes, depositada en el archivo de la Capilla Alfonsina, contiene 47 piezas, algunas de ellas notas muy breves, dos tarjetas personales y un telegrama. Dos cartas de pocas líneas se escribieron en México antes de la salida de Reyes a Europa; una, también desde México y enviada a Madrid; otra, de La Habana a Madrid (estas dos últimas y una de las primeras ya están recogidas en este trabajo); una más desde Buenos Aires a Madrid; un telegrama al partir de México a España en 1922, al concluir su visita al país. El resto está enviado y recibido en Madrid, o desde Madrid a París y Buenos Aires, ciudades en las que Reyes desempeñaba sus misiones diplomáticas. Es decir, con excepción de las primeras cinco cartas y el telegrama citado, 42 cartas fueron escritas por Urbina en España.

La correspondencia de Urbina presenta una dificultad, pues la mayor parte de las piezas llevan como fecha el día del mes, pero en muchas falta el año, e incluso el lugar desde el que se envía la carta. Es necesario desprender, del contenido de estas piezas, su procedencia y su fecha exacta, lo cual no en todas es posible. Sin embargo, una vez realizada esta tarea, el material permite ubicar en el tiempo aspectos importantes del pensamiento, los problemas, estados de ánimo y circunstancias de la vida de Urbina en los 19 años que cubre dicha corrèspondencia, de 1911 a 1930 , y sobre todo sus impresiones y juicios sobre la vida y la obra de Alfonso Reyes. En todas las cartas y mensajes de Urbina a Reyes, sin excepción, se mantiene inalterable la expresión de afecto y amistad, revestida en la mayoría de los casos de ese tono, mezcla de ternura, sensibilidad y dolor callado de la vida, característico del estilo del poeta de la "vieja lágrima". Al paso de los años, las cartas del hombre adulto que se dirige al joven se convertirían en las del hombre viejo que se siente marginado de las nuevas corrientes literarias, ve las posiciones que va conquistando su amigo y su proyección en el ámbito hispanoamericano desde París y Buenos Aires, y opta finalmente por su "rincón de olvido".

Pero al llegar a España en 1916, con 52 años de edad, Urbina tiene todavía vigor y entusiasmo para iniciar nuevas empresas. En el mes de agosto, poco tiempo después de instalarse en Madrid, aparece el primer número de la revista Cervantes, realizada por Urbina en colaboración con Francisco Villaespesa, el poeta 
modernista. Por esas fechas llega también a Madrid Isidro Fabela, enviado por don Venustiano Carranza a Europa en misión diplomática, para obtener la reanudación de relaciones con varios países, y con destino final en Buenos Aires como ministro plenipotenciario de México. Fabela invitó a su amigo Urbina a viajar a la capital argentina para dictar conferencias sobre literatura mexicana; Urbina llegó en abril de 1917 a Buenos Aires, donde permaneció un poco más de tres meses. Poco antes de partir, el 4 de abril, Urbina le entregó personalmente a Alfonso Reyes esta carta:

Muy querido Alfonsito:

Con el pie en el estribo, gran señor, ésta te escribo. No pude verte; no pudiste verme; no pudimos vernos. Los que tiramos del carro no tenemos tiempo de nada. Aquí te dejo mi saludo muy respetuoso y amable para tu mujer, para tu simpática compañera, un beso en la frente de tu hijo, el que prolongará tus anhelos de vida mejor, y dos grandes abrazos para ti, uno de estimación muy sincera y otro de cariño muy grande. A la vez, te recuerdo mis encargos, y entre ellos, el de que entregues al Sr. Rodríguez Marín el libro que te llegará con esta carta. Mándame tu volumen apenas salga.

¡Que no me olvides!

Fraternalmente tuyo.

Luis

Mientras estaba Urbina en Buenos Aires, Alfonso Reyes recibió en Madrid una carta de Manuel J. Sierra, el hijo de don Justo, pidiendo apoyo y la búsqueda de un abogado para iniciar un juicio contra los editores que en España habían publicado, sin permiso de la viuda de don Justo Sierra, su Historia política, e informando además que se había pedido la confiscación de la edición. El 24 de mayo escribe Reyes a Buenos Aires, informando a Urbina la petición y postura de Manuel J. Sierra en relación con el libro de su padre editado en España:

Mi querido Luis:

Nada ha habido en la prensa sobre nuestros libros: nada te he enviado por eso. Del mío sólo recibí 50 ejs. que ya distribuí, y como en ninguna librería aparece, y ha pasado ya tanto tiempo, me he dirigido a un $\mathrm{Sr}$. Yagues - a quien me remite Galo el impresora ver si él me puede hacer enviar los otros 50 ejs. que pedí. Villaespesa, con las prisas del viaje, apenas me presentó con cierto señor Llorens, o cosa parecida, diciéndome que él quedaba encargado de 
todo, pero de quien no he vuelto a saber palabra. Ayer me dijo cierto amigo que mi libro, aunque no aparece aún por las librerías, está ya en las tiendas de lance del Horno de la Mata: cosas de Villaespesa. Esto es lo que en nuestra tierra llamamos "chotear la mercancía".

He recibido carta de Manuel Sierra en que me precisa estos tres puntos: $1^{\circ}$ Que le envíe un ejemplar de cierta edición que saben se ha hecho en Madrid de la Historia política de D. Justo, obra que como todas, está registrada debidamente y es ahora propiedad de la Viuda (y añade: el único patrimonio de mi madre está en las obras de mi padre); que ya han avisado que dicha edición sea recogida. $2^{\circ}$ que le dé abogado de confianza a quien enviar poder para este negocio. $3^{\circ}$ que hable contigo del asunto. Hice algunas averiguaciones, y tuve ocasión de preguntar a Blanco Fombona si era él quien se proponía hacer esta edición, para que en tal caso, evitando dificultades, se pusiera antes de acuerdo con la familia Sierra. Me dijo que no, pero que sí existía tal edición, y no me quiso decir dónde, y aun creo que se interesó en el asunto. Sin embargo, yo pude averiguar que tal edición formaba el tomo VI de vuestra Colección Cervantes, y no he podido examinarla, aunque no se ha puesto a la venta, y enviaré a Manuel el ejemplar que solicita. En cambio, no le hablaré de abogado ni cosa parecida, porque lo que menos sospechaba él es que podrías tú estar interesado en esto, y creo que tratándose de ustedes, todo se arreglará a satisfacción de ambos. Si en algo te puedo servir a este respecto, ya sabes que cuentas conmigo. Sé feliz, saluda a los amigos, y escríbeme algo de lo que te haga sentir aquella tierra. ¿Qué de tus proyectos? ¿Volverás a ésta? En tal caso, no te asocies más con Paco.

Te abraza muy cariñosamente tu fraternal

A.R.

Esta carta y dos de respuesta a Manuel J. Sierra (1 de junio y 3 de julio de 1917) son las únicas de Alfonso Reyes en el expediente de la correspondencia de Urbina, porque fueron escritas a máquina y se conservó la copia. Reyes, espíritu conciliador, buscó que el problema se arreglara sin la intervención judicial. La respuesta de Urbina no se hizo esperar:

Buenos Aires, julio $1^{\circ}$ de 1917

Mi querido Alfonsito: Recibí tu carta. Me dice ella lo que me temía respecto de tu libro. ¡Cómo sentí no dejar arreglado esto! Sé bien lo disgustado que estarás. Tanto como yo. Espero que para cuando recibas esta carta el asunto esté terminado en cuanto a la aparición; en cuanto al negocio será preciso que me esperes. No tardaré en regresar, según mis cálculos y mis deseos. He apartado ca- 
marote en el "Reina Victoria", que si no sucede nada gordo, saldrá de aquí el 2 del próximo agosto. Si para entonces no te han liquidado, entraré en campaña y venceremos. $A$ dos garrochas no hay toro valiente. Yo he hecho ya atmósfera argentina para la llegada de tu libro. Caerá bien, te lo aseguro. Y yo quedaré encantado de tu triunfo. ¿Qué lástima de retardo! ¡Maldito sea el queso!

Lo de la edición de Don Justo, y la carta de Manuel, es cosa que me contraría horriblemente. En efecto: para evitar la rapiña de la obra, intentada ya por otra casa, la misma de que me hablas, el mismo sujeto que está viviendo de cogerse los libros, hice anunciar en la "Colección Cervantes"' la historia del maestro. Logré parar el golpe. Y permití que Paco Villaespesa diera a conocer los primeros capítulos. Pero nada hubiera yo hecho, ni permitido hacer, sin dirigirme antes a la Familia Sierra. Y en el caso de que me obligaran los ladrones del otro lado a la publicación, el producto integro de la edición, hubiera ido inmediatamente a manos de la señora. Sin embargo, por cable hubiera yo solicitado el consentimiento. Y no saldría una línea sin que yo hubiera corregido las pruebas. Estos dos eran mis deberes imprescindibles. No encontré otra manera de evitar un latrocinio como el que le hicieron a la Viuda - ipobrecita!del Duque Job, que parando el golpe con el anuncio. Convinimos Villaespesa y yo en que nada se publicaría de Don Justo antes de que yo regresara a España. Me figuro lo que sucedió: el hombre, para salir de apuros, para dejar dinero en su casa, recurrió al "México y su evolución social", y cometió la falta. ¡Ahí va!, sin decir nada, sin pensar nada, en su atolondramiento normal, acrecentado por las necesidades del viaje.

¿Qué horror! No es sólo lo del dinero; es la reputación de Él que yo cuido como mis propios ojos. ¿Qué libro será ese lleno de erratas, de disparates, de abominaciones! Esto, a pesar de mi cachaza, me tiene fuera de mí. Razón tiene Manuel, y dile que sí; que proceda; que nombre abogados, que haga cuanto se necesite para que este negocio quede en claro, y la señora no sea hurtada en sus intereses y no sea profanada la memoria del Maestro. Seguiré tu consejo. No más Paco. Amigos sí, pero socios no. No nos entenderemos nunca. Él vive a la picaresca; y yo no puedo vivir así. ¡Si tú lograras evitar que saliera esa malhadada edición! ¡Si fuera tiempo todavía! ¡Inténtalo! Te lo agradeceré mucho. Dile o transcríbele todo esto a Manuel.

Ahora, cinco líneas sobre tu amigo. Veladas, artículos, informaciones de periódico, retratos de Seminarios, comidas... Ingenioso, cordialísimo, es mi cicerone; me ayuda de verdad y con gran desinterés en la misión intelectual. Lugones, fraternal, lleno de camaradería; un poco retraído. Los muchachos de "Nosotros", un encanto. Muchas invitaciones a fiestas y veladas. Un curso de " $\mathrm{Li}$ - 
teratura mexicana" en la Facultad de Filosofía y Letras de la Universidad de Buenos Aires. Esto es lo serio. Cinco conferencias seminarios. Me falta una solamente; que daré dentro de seis días. Un trabajo muy pesado para ordenar, para sintetizar, para doctrinar. Un éxito enorme. El aula, que es más amplia, se repleta hasta aquello del alfiler. Ya verás mis apuntes; ya me harás indicaciones. La labor ha sido fuerte. Creo haber cumplido. Te contaré muchas cosas de acá. Esta vida es interesantísima. Saluda a tu mujer. Besa a tu niño. No me olvides. No me culpes. Dale un abrazo de mi parte a Pancho Icaza y recibe para ti, uno que te ahogue. Muy tuyo.

¡Hasta dentro de un mes!

Luis

La recomendación de Alfonso Reyes: "No te asocies más con Paco", y la respuesta de Urbina, confirma la imagen de desorden que caracterizó al poeta Francisco Villaespesa, fincado en la poesía y ajeno a los elementales aspectos prácticos de la vida. Juan Ramón Jiménez lo recuerda en los inicios del siglo, entregado a la poesía, "atravesando puertas, paredes y techos, como si fueran aire, en el mismo estado de inconciencia disparatada, entreabierta siempre la boca, molde palpitante de la palabra de su rito, fija la vista, tras los lentes de su miopía, en su fin"'5. Al comunicar Reyes a Manuel J. Sierra la respuesta de Urbina (30 de julio de 1917), dice de Villaespesa que tiene "el temperamento atolondrado de los "vates"". Es posible que el problema haya sido resuelto e interrumpida la continuación del trabajo editorial. En todo caso, ese mismo año viajó Villaespesa a México y es probable que hayan hablado él y Manuel J. Sierra. En cuanto al amigo de Reyes que cumple con Urbina funciones de cicerone en Buenos Aires, no ha sido posible identificarlo.

De los libros que mencionan ambos, el de Reyes es El suicida, publicado ese año de 1917 en Madrid, en la Imprenta de M. García y Galo Sáez. Antes del viaje a Buenos Aires, Urbina envió a Reyes tres mensajes, dos sobre su libro; el primero, de febrero 9, dice: " $\mathrm{Mi}$ querido Alfonsito:/Me urge verte para arreglar el asunto de tu libro. Te espero el domingo próximo en la mañana antes de las once./ Te quiere tu fraternal/ Viejecito." El segundo no tiene fecha: "Mi querido Alfonsito:/ Tuve que salir impensada y violentamente a Barcelona para arreglar asuntos editoriales. El martes estaré de regreso. Te espero. Es urgente que te vea./ ¿ $\mathrm{Me}$

5 JUAN RAMÓN JiMÉNEz, "Recuerdo al primer Villaespesa. 1899-1901", La corriente infinita. (Crítica y evocación), Aguilar, Madrid, 1961, p. 67. 
perdonas la tardanza?/ Siempre tuyo/ Luis." El tercero, del 24 de marzo, es aún más breve que los anteriores: "Sr. D. Alfonso Reyes./ Presente./Ven mañana domingo a corregir pruebas de diez a once de la mañana./ Tu hermano/ Luis".

El libro de Urbina es La literatura mexicana durante la Guerra de Independencia, en el que recogió el texto originalmente aparecido como Introducción a la Antología del Centenario y publicado en la misma casa impresora de El suicida. Ese mismo año Luis G. Urbina publicó una Antología romántica y La vida literaria de México ${ }^{7}$, donde recoge los textos de sus conferencias de Buenos Aires.

Al finalizar el año de 1917, Luis G. Urbina viaja a México, donde permanece seis meses. Es nombrado por el presidente Carranza Primer Secretario de la Legación Mexicana en Madrid, ocupando el puesto que había dejado Amado Nervo, y se embarca el 16 de julio de 1918 con rumbo a España. Duraría en el cargo hasta el 10 de junio de 1920 (el 21 de mayo el presidente Carranza muere en Tlaxcalantongo); ese mismo día, Alfonso Reyes es nombrado Segundo Secretario y medio año más tarde pasa a ser Primer Secretario. En estos dos años Luis G. Urbina vivió el periodo más desahogado económicamente en Madrid.

El 8 de octubre de 1918 murió en la ciudad de México el pintor Saturnino Herrán. Con este motivo, el 27 de noviembre de ese año escribió Urbina a Reyes unas sentidas líneas:

Mi querido hermano Alfonso:

Acabo de recibir una noticia tristísima: la muerte de Saturnino Herrán. ¡Pobre muchacho! ¡Tan bueno, tan manso de corazón, tan naturalmente artista, tan hinchado de entusiasmo y esperanza! Cuando hace cinco meses lo dejé, ya estaba enfermo. Paliducho, larguirucho, cargado de hombros, con su abierta sonrisa que enseñaba las encías amoratadas, con sus grandes y cansinos ojos de tísico! Estaba muy pobre: había cometido la locura amorosa de casarse, y la otra locura consoladora y tristísima de tener un hijo. Locuras las dos porque él sabía que vino al mundo muy mal herido. Yo conocí a su padre: un tuberculoso que pasó por la vida - una vida cortadelirante de talento y de amor. Saturnino - ¿te acuerdas? - dibujaba como un exquisito; pintaba como un maestro. Deja una obra apenas comenzada; un despunte de aurora. Tenía muchos proyectos, mucha fe en sí mismo; mucha existencia por delante. De buena gana me lo hubiera traído a ver a Velázquez a quien tanto amaba.

${ }^{6}$ Ed. Araluce, Barcelona, 1917.

7 Imprenta Hnos. Sáez, Madrid, 1917. 
Venir al Prado era su sueño incesante.

Y ahora. . U Una flor que cae: nuestro jardín se va despoblando.

Hasta luego, viejecito. Te escribo estas líneas a lomo de caballo, aprovechando un minuto de mi mañana dịplomática. Te escribo para desahogarme de este minuto de pena y de nostalgia. Te escribo porque veo que tú también piensas en Saturnino Herrán.

¡Pobrecito! Ruega a Dios por él.

Te quiere mucho.

Luis

El 15 de diciembre de 1918 escribe Urbina a Reyes una breve nota:

Hermano:

Me escribe Juan B. Delgado anunciándome que has sido elegido miembro correspondiente de la Academia Mexicana. Que en ello se empeñó mucho Pepe López Portillo. Que Delgado te felicita.

Yo te mando un abrazo. Muy tuyo.

Luis

Alfonso Reyes leyó en la Academia su discurso como miembro correspondiente, cinco años y medio después, el 20 de junio de 1924, en ocasión de su viaje a México ${ }^{8}$.

Cuatro días después del anterior mensaje, el 19 de diciembre de 1918, Urbina dirigió otro a Reyes:

Mi querido Alfonso:

He leído tus dos estudios. Muy curioso el de Paravicino. Muy interesante el de Góngora. Pero como este segundo es continuación de otro llamado "Los textos de Góngora", me han quedado las ideas un poco deshilvanadas e incompletas. ¿Serías tan bondadoso de buscarme un ejemplar de "Los textos..." y remitírmelo con el prometido libro grande sobre Ruiz de Alarcón? Mira que cuanto escribes - que ya es muy serio- nutre mis aficiones y me enseña mucho. Ya sabes que soy un curioso infatigable./ Te quiere y te admira tu hermano./ Luis.

Los dos estudios son "Las dolencias de Paravicino" y "Reseña de estudios gongorinos, 1913-1918", publicados ambos en el número 3 de la Revista de Filología Española. El anterior, "Los textos de Góngora”, se había publicado en la misma revista dos años antes.

${ }^{8}$ Incluido en la Quinta Serie de Simpatias y diferencias, AROC, t. 4, pp. 437-440. 
Al finalizar 1921 Luis G. Urbina regresa a México a invitación del gobierno, que le proporciona viáticos y pasajes y le ofrece trabajo en la ciudad de México. Aquí permanece hasta el mes de junio de 1922, y regresa a España con un nombramiento de la Secretaría de Educación Pública como Primer Secretario de la Comisión "Francisco del Paso y Troncoso". El 10 de septiembre escribe a Alfonso Reyes (la carta no menciona el año, pero por lo que se dice en la parte final se concluye que es de 1922):

Mi muy amado Alfonso:

Estoy aquí, como devota en ejercicios, en un delicioso retiro espiritual. ¿Que cómo vine, preguntas? Pues casi ni lo sé; por un prodigio de la suerte, combinado con un esfuerzo de la voluntad. Yo he de contarte todo eso, letra a letra, y latido a latido. Pero antes necesito, por imperioso mandato de mi cariño, decirte que siempre soy, siempre he sido y seré siempre tu hermano mayor, atento, amoroso, imperturbable en los vaivenes de la pasión y del destino. Siempre fuiste y serás una alma selecta que desenvuelve ante mí sus maravillosas facultades pensativas y sensitivas. $\mathrm{Y}$ yo hago que $\mathrm{mi} \mathrm{co}^{-}$ razón tome parte en el espectáculo.

¿Quién recuerda bajezas y escorias? Nuestra amistad vive y ve más alto. Como que toda ella está llena de amor, de piedad, de sinceridad. Dichosos nosotros que podemos querernos y estimarnos así.

Tu recuerdo me ha acompañado en mi peregrinación.

He sabido de tus triunfos y me he enorgullecido. No te decores la gloria con una lágrima de amargura. Para que ella resplandezca no necesita diamantes efímeros.

Deja que rastreen los envidiosos. Tu carta me dio tristeza porque me reveló un aleteo azorado de tu inquietud. No. Acabo de comprobarlo. Tienes muchos amigos que te quieren, que te admiran y que están contentos de ti. Yo, naturalmente, soy del coro que canta el himno.

Adiós, Alfonsito mío, escríbeme; reanudemos la confidencia.

Bueno, se me olvidaba decirte que he venido a hacerme cargo de los papeles "Del Paso y Troncoso", y a seguir mis investigaciones archivescas. El pretexto para una escapatoria. Además me ha ascendido un poco el periódico. De modo que puedo dormir sin sobresalto y yantar sin escasez, durante mi tiempo de silencio y de olvido. ¡Qué fortuna!

Dale mis recuerdos a Manuelita, besa a Alfonsito. $\mathrm{Y}$ si ves a Manuel Ponce dile que lo quiero y lo admiro como siempre y que con frecuencia pienso cariñosamente en él y en su buena compañera.

Para ti mis abrazos estremecidos. 
El año de 1923 Urbina publicó cuatro libros, dos en México (Psiquis enferma y Hombres y libros), uno en Madrid (Luces de Espa$\tilde{n a}$ ) y otro más en París (Poemas escogidos). Luces de España se lo envió a Reyes con carta del 1 de marzo (no se indica el año, pero puede identificarse por la mención del libro). Al final de la carta se refiere a su salud y a su estado de ánimo: "He estado achacoso y tristón". Quince días más tarde, el 16 del mismo mes y año (ahora sí señalados ambos), Urbina le envió otros dos, sin mencionar cuáles son:

Entre las rancias manías que me quedan, una de las irrefrenables es ésta de enviar a mis amigos mis libros, con dedicatoria y todo, como en los tiempos del Gallo Pitagórico y de Don Juan Mateos. Ahí van esos dos últimos volúmenes. Los primeros ejemplares son, como siempre, para ti.

La carta termina con la expresión del que siente que se va quedando atrás frente a las nuevas expresiones literarias:

Sé muy bien que, intelectualmente, no te interesan. A ningún moderno interesan ya estas antiguallas mías. Y por eso, no te los mando para que los leas, sino sólo para que los pongas en cualquier rincón de tu biblioteca, como recuerdo de un amigo viejo que te admira mucho y te quiere más.

Por su contenido, dos cartas más pueden fecharse en el año 1923; una, con la mención "marzo 21", en la que Urbina acusa recibo a Reyes de un libro de versos (Huellas); la segunda, en la que se refiere al escándalo suscitado por un libro de don Francisco A. de Icaza, Diccionario de conquistadores y pobladores de la Nueva España, publicado en junio de ese año en Madrid. Urbina escribe a Reyes pero no se pudo identificar dónde se encontraba éste, posiblemente de vacaciones fuera de Madrid:

Agosto 29

Sí, mi bueno y querido Alfonsito, en Madrid estoy sufriendo los rigores de un verano implacable. Tú ya comprenderás que esta forzada penitencia, esta casa que es un horno para las carnes, este sol que es como un estilete para los ojos, me tienen enfermo. Pero ¡qué le vamos a hacer! Para estos pequeños males se han hecho las ayudas de paciencia que recetaba Lope.

Efectivamente: he leído ese escándalo con que recibieron en México a Icaza. No conozco de esta batalla más que el lado del ataque. 
No recibo sino Excélsior. Como a ti, me ha apenado mucho el incidente. Hay en esta aparente investigación de la verdad un sedimento sucio, un pozo de malas pasiones que van acaso desde el resquemor hasta la envidia. Me figuro que la defensa de Icaza debe de haber sido muy acre y muy despectiva, lo que habrá irritado la furia de sus contrincantes. De cualquier modo que sea, el ataque, creo yo, ha sido mezquino, enconado e injusto. No me parece una polémica de Ateneo, sino un asalto de encrucijada. Entre tanta hipótesis, conjetura y negación de conocimientos, no veo la prueba del plagio. Siento, sin embargo, la mala voluntad. Esto mismo que te digo, muy ampliado y muy golpeado, se lo escribí a Pepe Núñez y Domínguez, que es el único que, en carta última, me habla del asunto. Nicolás Rangel no me ha puesto una letra desde hace dos meses. Si se comunica conmigo le diré lo mismo. La inquina y la crueldad contra un hombre de tantos méritos y servicios como Pancho Icaza, es un caso de inconciencia o de perversidad. Me hago cargo del sufrimiento de ese espíritu, tan quisquilloso, tan llagado por los alfilerazos y lanzadas de la suerte. Un horror, Alfonsito.

Pues has de saber que Núñez y Domínguez me dice que hubo un defensor de Icaza que, sin dar mi nombre, insinuó que yo, desde aquí, desde Madrid, dirigía la campaña. Pudiera ser que el mismo Icaza, nuestro caviloso Pancho, sugiriese la perfidia. Yo le dije a Núñez y Domínguez, mire usted: los que se entretienen en observar cucarachas con lupa, ven monstruosos y espantables estos insectos. A la simple vista no son sino unos bichos asquerosos. Así, la calumnia. No me importa. Sé que cuando vuelva la luz y barran, desaparecerán calumnias y cucarachas. Esperemos la hora del aseo.

Fíjate: no conozco el libro de Icaza. No he visto en mi pambacera vida los papeles del Sr. Del Paso y Troncoso. ¡Qué tontos o qué malignos los que me meten en estas andanzas, entre las cuales - según veo- andas tú en tu noble papel de admirador y alentador de un elevado y tenaz esfuerzo!

Por todas estas cosas, considero probable que se venga abajo la comisión. He aquí el verdadero y doloroso resultado de estas riñas de prensa. ¡Cómo minusculiza (¡perdón por la palabra!) el alma, el polvo de los archivos, el trato con la paleografía! Ante estas fatalidades no hay que perder la tranquilidad. ¡Dios dirá, hermano! Acuérdate del fatalismo de nuestros pelados: ¡Ya sería mi costelación, patroncito!

El calor, que ha sido durante muchos días de poner a uno en agonía, me ha vuelto papilla el cerebro, me lo ha convertido en el líquido humor de Sor Juana (y no son lágrimas las mías sino sudores). No he podido trabajar. Estoy retrasado en mis labores. Espero con ansia días frescos, noches tranquilas. Si ves a Serrano o a Alducín, salúdalos en mi nombre. 
Aquí tienes a tu amigo, a tu viejecito amigo, agotado por la temperatura, abatido por la pobreza, y en espera de no sé qué obscuro y triste... Saluda afectuosamente a Manuelita, besos al niño. Abrázate en mi nombre.

Muy tuyo

Luis

Escríbeme si puedes. ¿Cuándo regresas? Me estás haciendo mucha falta.

Una referencia a esta acusación de plagio puede verse en el estudio preliminar a las Obras de Francisco A. de Icaza. ${ }^{9}$ La parte final de la carta toca de nuevo el tema personal, que empieza a ser reiterativo, del desaliento, añadiéndose ahora la referencia a la pobreza, condición que ya no se separará de la vida del poeta. Una mezcla de fatalismo y resignación ante las circunstancias que cada vez lo limitaban más.

El año de 1924 se inicia con una carta de quejas por la incomprensión de quienes en México debían proveer el envío de fondos a Urbina, como secretario de la Comisión "Del Paso y Troncoso"; también es de agradecimiento a Reyes y a Enrique González Martínez (quien se encontraba en Madrid como Ministro plenipotenciario de México en España y Portugal) por el apoyo recibido en esa época difícil, y referencia a sus trámites para ser aceptado en El Universal como colaborador:

Madrid, enero 29

Alfonso mío:

Tu carta del 24 me llena de consuelo. Me promete sesenta días de pan. González Martínez y tú me ayudarán a que, por un tiempo, pueda orientarme y calcular la solución de mi problema. No sé si sabrás que, de México, me niegan los viáticos. Ni poco ni mucho: nada. Me parece algo inmoral el acuerdo. Los emigrantes y aventureros suelen conseguir la repatriación. A mí no me suspendieron por incumplimiento ni por mala conducta. Fue por econo-

${ }^{9}$ Francisco A. De ICAza, Obras, ed. y estudio preliminar de Rafael Castillo, FCE, México, 1980, pp. 103-106. Sobre la Comisión "Francisco del Paso y Troncoso" véase Silvio Zavala, Francisco del Paso y Troncoso. Su misión en Europa, 1892-1916, Instituto de Estudios Históricos, Biblioteca del Claustro de Sor Juana, México, 1980 (ed. facs. de la del Museo Nacional, México, 1938). 
mía patriótica. ¿Tenía yo derecho a solicitar... ? En fin, ha pasado. Tú sabes lo difícil que está Madrid para vivir de la pluma. Acaso "El Sol" me ofrezca una colaboración de quince duros mensuales. Tú verás.

He escrito a Miguel Lanz Duret, pidiéndole una de estas dos cosas: aumento de trabajo y situación de unas pesetas aquí, o envío de mil quinientos pesos para regresar a México y trabajar en ese pandemonium de pasiones. Es decir, naufragar. ¿Qué voy a hacer de serio, durable ni definitivo, en el trajín de un periódico político? Aquí del proloquio: nadar, nadar, y en la orilla, ahogar.

He pensado, Alfonso, que tal vez Arturo Pani, que es tan bueno, esté dispuesto a escribir a Alberto, exponerle mi situación y pedirle cordialmente ayuda. No he hecho nada malo ni bochornoso para que me dejen así. He procurado representar, a mi modo, la cultura de México. He trabajado, con ahínco de mejorarla. ¿Qué piensas de esto? Nada haré sin tu consejo y tu apoyo.

Y. . hasta luego, mi Alfonso, que estoy un poco quebrantado. Gracias. Gracias. Gracias.

Mis saludos a Manuelita. Mis besos al niño.

Acuérdate de tu viejecito amigo

Poco después, el 12 de marzo de ese mismo año, Urbina informa a Reyes la respuesta de El Universal:

Mi querido Alfonso: Para darte buenas noticias, las esperé de México, y retrasé unos días la contestación de tu carta y el acuse de recibo de las quinientas de marzo. Me has hecho un gran bien, no sólo material, sino espiritual, porque siento que tengo en ti a un amigo fiel, comprensivo y generoso. Tu mirada ha sabido ver el fondo de mi vida. Y ese interés no te lo puedo pagar más que con mi cariñosa confianza en ti. Yo también te veo y te comprendo.

Has de saber. . ¿ ¿Te acuerdas que propuse dos soluciones a "El Universal'? Pues bien: a fines de febrero recibí un cable que decía: Primera solución. Luego, a principios de marzo, me escribió Miguel Lanz Duret, diciéndome, textualmente: "Respecto del asunto de sus viáticos, he estado tratando con Manuel Sierra, quien a su vez ha estado viendo al Sr. Dn. Genaro Estrada, y veo tan bien encaminadas las gestiones de aquello, que juzgo casi seguro que se le remitan en breve"'. Hace dos días recibí otra carta de Lanz Duret, confirmándome el cable, y diciendo: "Efectivamente, en vista de la difícil situación en que se encuentra usted, he decidido aceptarle, además de los cuatro artículos que mensualmente hemos convenido, dos más para “El Universal Ilustrado" mediante un pago total de $\$ 350$ al mes, que se repartirán como sigue: A usted $\$ 200$ en Madrid; a su familia, en México, $\$ 150$ ”. Y en seguida agrega: "Ya 
estoy arreglando, por conducto de mi cuñado Manuel Sierra, que le giren a usted sus viáticos. En caso de que se los manden, espero se sirva decirme inmediatamente si resuelve venir o quedarse allá, para arreglarnos respecto de su colaboración".

Hasta estos momentos no recibo aún dinero ninguno de " $\mathrm{El}$ Universal"'; nada hay de positivo todavía; pero, como ves, la situación está cambiando en mi favor, y parece resuelto mi problema en el porvenir. Por de pronto, me salva el oficio. Poco ganaré, pero no me moriré de hambre. Aquí nos apañaremos gentes y animales para bendecir la vida humilde; y en México, Lucesita, aunque mermada en algo su mensualidad, no quedará abandonada. ¿Te parece bien?

Ahora, veremos lo de los viáticos. Yo te diré lo que resulte, tan pronto como lo sepa.

Esta carta que es de transcripciones necesita una, que es curiosa. Mira: me escribió el poeta Luis Quintanilla, agradeciéndome la cordialidad de un juicio severo que le hice acerca de sus poemas, y me dice (textual): "Y usted qué hace? No se aleje de nosotros. El otro día, hablaba yo de usted con el doctor Puig Casauranc, y me decía él que usted no quería venir a México. ¿POR QUÉ?" Así, con letras mayúsculas me hizo la pregunta.

Tú verás si sonríes. Yo sí, con un poco de amargura. Esta temporadita me ha quebrantado la salud. El ánimo está como siempre. Estas penas pequeñas que, según el poeta, son las que hacen daño, se me han acumulado a última hora, cuando resbalando por la rampa, voy a llegar a los sesenta.

Por eso me dio triste risa leer este viejo refrán, que me encontré en el último libro de Menéndez Pidal: "A la ramera y al juglar, a la vejez les viene el mal'".

Hoy estoy por las transcripciones. Perdóname la lata.

¿Cómo está Manuelita? Me supongo que bien, como lo deseo. Besa al niño... no olvides a tu hermano.

¿Y tú? Escríbeme cuando puedas. No rompas el hilo con tijeras de silencio. - Yo, cuando menos, he de escribirte cada mes.

Luis

Al final de la carta Urbina escribió que "resbalando por la rampa, voy a llegar a los sesenta". Había nacido el 8 de febrero de 1864 , o sea que ya había cumplido esa edad pero afirmó siempre que su fecha de nacimiento fue el 8 de febrero de 1867, y esta circunstancia podría explicar la mención a su "próxima"' edad sexagenaria ${ }^{10}$. La primera colaboración que envía Urbina a $E l$

${ }^{10}$ Quien descubrió la fecha exacta del nacimiento de Luis G. Urbina (fi- 
Universal en ese año de 1924 se publicó el 11 de mayo y es la crónica de la despedida de los amigos de Madrid a Alfonso Reyes, quien había concluido su trabajo diplomático en España, en el Restaurant Lhardy ${ }^{11}$.

Reyes regresó a Madrid a finales de octubre de ese año de 1924, en misión especial ante el rey Alfonso XIII. Permanece allí aproximadamente dos semanas, tiempo en que seguramente conversó con Luis G. Urbina, pero no hay ninguna referencia de esto en el archivo.

El cinco de noviembre ya está Reyes en París, dispuesto al regreso; recibe instrucciones de esperar ahí su destino diplomático. Se hospeda en el mismo edificio donde murió Marcel Proust (44, Rue Hamelin). En diciembre es designado Ministro y queda al frente de la Legación de México en Francia. El primero de enero Luis G. Urbina reanuda su correspondencia con Reyes:

\section{Sr. Dn. Alfonso Reyes}

Mi querido hermano Alfonso:

Ahora sí puedo escribirte para decirte algo. Esperaba noticias que comunicarte y ayer me llegaron por conducto de nuestro amigo el Coronel Pérez Figueroa, porque Enrique y sus secretarios andan, en estos días, por Sevilla. Un cable. Cesa la Comisión del Paso y Troncoso. O lo que es lo mismo me quedo, desde hoy, sin pan y sin esperanza. Lo temía; lo presentía. Pero, aunque mi vida, que ha sido turbulenta, sabe ya ser un Tiberíades por el que pasa Dios serenamente, aquí me tienes un poco acongojado y decaído. La situación - tú lo comprenderás, Alfonsito- no es para menos. Lo material me aflige, y, te lo confieso, algo también lo moral. Lo que importa es precipitar la vuelta a México - no podrá ser antes del diez y nueve- porque no sé como voy a apañarme... veremos. Mucho estoy temiendo que me escatimen, al céntimo, los viáticos; no podré entonces llevar mis libros, la mayor parte de ellos indispensables para mis trabajos. Para mí, eso sería una catástrofe. La joroba molesta, pero hay que aguantarse, como dice la copla.

jado en 1868 en todas las historias de la literatura) fue Gerardo Sáenz, de la Universidad de Arkansas, quien explica en su biografía del poeta que no existe acta del Registro Civil del nacimiento de Urbina porque ese año no hubo ese servicio, y pudo encontrar el acta de bautizo porque la hija de Urbina le dijo que su padre afirmaba haber nacido el 8 de febrero de 1867. Cf. GerarDo Sáenz, Luis G. Urbina. Vida y obra, Ediciones de Andrea, México, 1961, p. 7 y p. 15 , nota 2 .

11 Véase nota 2. 
De cualquier modo, yo tenía dos intranquilidades: la mía y la tuya. Las dos, con resoluciones contrarias, han desaparecido.

Tu nuevo triunfo, por encima de los resentimientos políticos, me satisface y me alegra lo indecible. La actitud de tu moral, la fuerza de tu entendimiento, tu corazón, tan fino, tu juventud tan emprendedora de bien, han sido reconocidos justamente, en esta ocasión. Esta prueba por la que pasaste, no sin dolor, afianzará tu porvenir. Adelante, Alfonso; a trabajar, a cantar, a vivir tu vida interior tan luminosa y $\tan$ ancha de horizonte. Aprovecha tu edad, la mejor década, la de los treinta y cinco a los cuarenta y cinco. Ya comienzas a paladearla, cuando me dices que tienes muchos deseos de trabajar y que empiezas a sentir más el goce y el dolor. Es que va subiendo tu sol: está cerca del cenit. Todas tus potencias crecerán, durante estos diez años, para darte la plenitud, física y espiritual. Ha comenzado para ti el verano. La pequeña herida de tu corazón se removerá constantemente. Déjala: no es una ventana, es un pequeño y escondido raudal de lágrimas, que refrescarán tu pecho con frescura de piedad y perdón. Te volverán más bueno todavía.

¿De Camila? ¿De mi perro y mi gata? Camila llora a escondidas. Me apena verla sufrir. ¡Tan angelical! ¡Tan abnegada! Una alma pura en un cuerpecillo insignificante; Jerez Agustín, en taza de barro pueblerino. Mi perro está echado en estos momentos, a mis pies, y mi gata es mi pisapapeles sobre mi mesa. ¡Y tener que dejar esta casita de silencio, de olvido, de calor íntimo, de labor apacible! ¡Qué le vamos a hacer!

Mil gracias, por tus cartas a los amigos. Acaso me sirvan para orientarme y ambientarme en México.

Voy a escribir una impresión de lector, acerca del Calendario y la Ińgenia. La Ińgenia, sobre todo, es un encanto. Me ha deleitado. Ya verás de qué manera.

Apólogos mínimos:

Los últimos pájaros (volando) a los que quedan con la cabeza fuera del nido: - ¿Y por qué no os atrevéis, vosotros? ¿Para qué tenéis las alas?

Los pájaros perezosos: - ¿Pero qué, no veis lo ridículo y pasado de moda de vuestro vuelo, que es como el nuestro? Imposible compararlo con el de esas grandes aves que ahora rompen el cielo. Son de palo, de tela, de hierro; pero qué ruidosas, qué veloces! Y además, llevan un hombre dentro. No; decididamente nos quedamos en casa. Tenemos miedo y vergüenza de los aeroplanos. Los aeroplanos echarán del aire a las golondrinas. Cantaremos en el alero.

El otro apólogo - el del manantial - queda para otra ocasión. Ya te di la lata. Adiós, Alfonso mío; besos a tu niño; saludos a Manuelita. Tu hermano 
La felicitación de Luis G. Urbina a Alfonso Reyes se debe a su designación como Ministro Plenipotenciario de México en Francia, hito importante en su carrera diplomática por la significación de la sede en el servicio exterior. Urbina, en cambio, entraba de nuevo en un periodo de dificultades económicas, al suspenderse los trabajos de la Comisión "Del Paso y Troncoso". En ese año de 1925 el poeta vivía en el número 7 de la calle de Fernán González, en compañía de Camila Ruiz Peñalver, su ama de llaves desde el tiempo en que habitaba en la calle de Claudio Coello número 70 (1919). Mientras, su esposa Lucesita y sus hijos permanecían en México, sosteniéndose con parte de los pagos de las colaboraciones de Urbina a El Universal. Dadas las condiciones de precariedad en que ahora se ve, habla de "precipitar la vuelta a México... porque no sé como voy a apañarme..."' Por eso queda en la carta la figura triste de Camila, que llora a escondidas. El apólogo de los pájaros, al final de la carta, es una clara alusión a su libro Los últimos pájaros, publicado en Madrid el año anterior, poesía que él considera anticuada ante la de su amigo, cuya Ifigenia cruel se había editado también en 1924.

El 20 de enero Urbina escribe de nuevo a Reyes, reiterando sus quejas por su situación tan comprometida y dejando mención del apoyo del ministro Enrique González Martínez para su regreso a México y su sobrevivencia en Madrid hasta el momento de su partida:

Mi querido Alfonso:

Comenzaré esta carta como empieza el Nocturno a Rosario: (¡Ay! Rosario, la muerta lejana...)

Pues bien, yo necesito recurrir a ti en esta situación tan molesta en que me hallo y que tal vez conoces ya por el relato de Guillermo Jiménez. Sí; nuestro ministro Enrique González Martínez puso el cable pidiendo mil dólares de viáticos y pago y transporte de mis libros. Pedí esa cantidad porque realmente tengo deudas por unos cuatrocientos duros - esas cositas que se van acumulando con la confianza imprevisora de que mañana se liquidarán. No quería irme de España como tantos mexicanos que personalmente contribuyen a aumentar el descrédito colectivo. Bien sé que si en otros tiempos fue posible que se me diera esa suma, ahora, acaso, no lo será. Pero, en fin, pedí para que se me ofreciera (martingala de comerciante). Han transcurrido quince días y el cable no ha sido contestado. Este silencio me indica una de estas dos cosas: o que no le han hecho caso o que la respuesta vendrá por correo. Esto segundo me parece lo más probable. Y si la suma que para viáticos me asig- 
nan ha de correr todos sus trámites burocráticos, no llegará la orden a Madrid sino hasta fines de febrero o mediados de marzo. (Figúrate los factores: nuevo ministro; principio de año; montones de oficios y nombramientos que firmar.)

Cogido en esta trampa casi por sorpresa, no me queda más que un recurso: no vivir, arrastrar la vida hasta marzo. Para ello, reducidos los gastos al mínimo, necesito seiscientas pesetas mensuales durante febrero y marzo. Así, pues, he imaginado un plan diabólico: que tú me prestes trescientas pesetas en febrero y trescientas en marzo, y que González Martínez me facilite igual cantidad en las mismas condiciones que tú. El presupuesto mensual está calculado así: treinta y cinco duros para la casa y ochenta y cinco para comida de mis animales, Camila y yo (arroz, patatas y judías en sus mil y cinco combinaciones). Un vaso de cerveza en bar de barrio cuando queden algunas pesetas sobrantes. Será difícil, pero...

Tengo, en ese caso, sesenta días para escribir, no a Genaro, a los amigos particulares a fin de que ejerciten su buena voluntad y su influencia para que se resuelva mi asunto, de cualquier manera que sea. Lo que gano en México, como sabes, es para Lucesita, que está en una larga y costosa agonía. No debo tocar eso. Es sagrado.

Ayer hablé a Enrique González Martínez de mi proyecto. Ya conoces lo bondadoso que es, y está dispuesto a prestarme ese servicio. (En enero me ha dado doscientas cincuenta pesestas.) Yo confío a ciegas, Alfonsito, en tu cariño. Confío también en tu estimación, en la fe que tienes de mi honorabilidad. ¿Puedes aceptar mi proyecto? Si puedes, no dudo de que me servirás.

No me quejo: comprendo los sucesos; los nuevos hombres, los nuevos problemas, las necesidades del ahorro y la contracción económica. Muy bien: así vienen los tiempos.

Si acaso me quedara yo abandonado aquí, buscaría, en esos dos meses, trabajo - ¡qué difícil! - para apañarme en una existencia de pocilga y sopa de ajos. La conciencia no se enturbiaría por eso; se entristecería un poco nada más.

Alfonsito mío: excúsame ya que conoces los esfuerzos que hay que hacer para no entrar, definitivamente, en la miseria negra.

Aguardo tu respuesta con la impaciencia que supones. Saluda a Manuelita; besa al chico.

Te abraza tu

La respuesta de Reyes debió ser oportuna y positiva. La siguiente carta la envía Urbina después de un poco más de dos meses, el dos de abril de 1925, fijando fecha para su salida a México:

Mi querido hermano: ¡Por fin! Ayer me dieron en la Legación 
la mitad de mis viáticos, y me guardaron la otra mitad para que no fuera yo a gastar más de lo conveniente, en vista de mis apuros y compromisos. Total: me enviaron de México seiscientos dólares, cantidad extraordinaria en las presentes circunstancias. Genaro, Manuel Sierra y los demás buenos amigos, estimulados por Miguel Lanz Duret, deben de haber contribuido a esta buena obra. Así pues, he pedido pasaje en la Trasatlántica Española, donde me rebajan el $30 \%$, para embarcar el 19 de mayo en Santander.

Nadie más que tú comprenderá lo que espiritualmente me cuesta arrancarme de este pedacito de tierra donde, olvidado, bebía savia de paz y contemplación. Nadie más que tú sabe el íntimo y callado dolor del agua de remanso que el viento remueve y lanza otra vez a las estériles borrascas. No es éste un lamento; es un contenido sollozo que llega a tu corazón, como tímida y avergonzada confidencia $-¿$ Cuándo, señor, me será dado volver a descansar? A Pepe Vasconcelos le debo cerca de tres años de tranquilidad espiritual. Ese periodo me hizo pensar en emprender una obra de arte alta y pura. Truncos quedan mis esfuerzos y quebradas mis aspiraciones. ¿Qué le vamos a hacer! Es preciso majar con el sudor de la frente el pan de cada día. Resignémonos.

No, mi amado Alfonso: los alfilerazos que ahora te da la vida, y que tú sientes como puñaladas, antes han de entonarte que abatirte. Están mojadas esas puntas en una gota de veneno de envidia. Pero ya lo sabes: "de la flecha del odio, sabe el viento".

Ahorrar hasta el sacrificio es, por otra parte, una vileza. Y luego, es una irreflexión. - Recuerda la sórdida existencia que llevó Amado Nervo, afín de Shylock - para no lograr ni siquiera la esperanza, ni siquiera la gratitud. Pero piensa en que es preciso prever: tu hijo puede hallarse un día incompleto y solo. Entonces, no será vileza sino alta virtud poner en sus manos elementos de porvenir. ¿Estás conforme?

No temas: tienes un gran corazón y una gran inteligencia. Las saetas vienen de abajo, de los que, desde las sombras, te ven subir. La impotencia y la mediocridad te zahieren. La señal es buena. Sonríe y canta. Esos dardos pequeños vuelven el alma fuerte y grande.

Por lo demás, parece que la vida de México se ha enturbiado un poco. Por tanto correr, el río se ha ennegrecido con el fango del lecho. Ya volverá la transparencia, y podrás mirarte en las aguas, como en un claro espejo.

Hermano mío: mi gratitud es grande, no tanto como mi cariño. No me olvides. Antes de partir volveré a escribirte.

Tuyo como siempre

A Manuelita mis saludos. A Alfonsito, mi beso. 
Los consejos de Luis G. Urbina a Alfonso Reyes obedecen a los ataques dirigidos a éste y publicados en los periódicos de la ciudad de México, mientras cumplía su función diplomática en París ${ }^{12}$

Efectivamente, Urbina escribió a Reyes antes de partir a México, como lo ofreció en su carta del dos de abril. Son sólo unas líneas de despedida y la promesa de escribir largo desde México.

Hermano Alfonso:

Madrid, mayo 13

¿Adiós? ¿Hasta luego? La despedida no es cosa mía; es del devenir. Es de Dios.

Voy al garete. Pero como la nave es vieja, conoce de estos peligros.

Ahora se me clavan los afectos en el corazón, como flechas. El tuyo desangra mi corazón. Nada más, mi Alfonso.

El diez y nueve salgo de España. -Es decir; no salgo; me arranco. Tú sabes todo lo que me cuesta, en la vida íntima, este desgarramiento.

Te escribiré de México largamente. ¿Quieres? Saluda a Manuelita; besa a tu chico. Repite a mi querido Arturo Pani mis agradecimientos. - Tuyo, como siempre, hermano mío.

Dirección: "El Universal", Iturbide 11.

Luis

Luis G. Urbina llegó a la ciudad de México el cinco de junio de 1925. Pocos días después, el 18 de ese mes, recibió el nombramiento de Profesor Especialista de Arqueología, dependiente de la Sección de Población Precolonial, del Departamento de Antropología, expedido por la Secretaría de Educación Pública, cuyo titular era el doctor José Manuel Puig Casauranc. Más tarde, el 28 de julio, se le comisionó para ocuparse en España de la clasificación de los documentos de la Comisión "Del Paso y Troncoso". Un día después, el 29 de julio, fue designado Secretario del Museo Nacional de Historia, Arqueología y Etnografia, para viajar a España con este cargo. Urbina se embarcó de nuevo con rumbo a España el 13 de agosto de ese año de 1925. Llega a Madrid en

12 Escribe Alfonso Reyes en su Diario, el 15 de marzo de 1925, refiriéndose a la recepción que le ofreció la Revue de l'Amérique Latine: "Aunque la fiesta fue, señaladamente, a mi persona, la he hecho derivar hacia México, cuya prensa diaria me injuria por estos días'" (Diario, 1911-1930, Universidad de Guanajuato, Guanajuato, 1969, p. 95). 
los primeros días de septiembre y a finales del mes siguiente reanuda su correspondencia con Reyes en París:

Madrid, octubre 221925

Mi querido hermano Alfonso:

Aprovecho uno de mis pequeños ocios en comunicarme contigo. No quisiera yo escribirte quejas, y isin embargo! Hace dos meses y casi medio más, que salí de México con mi pliego de comisión en el bolsillo: - la Secretaría de Educación me dio el encargo de recoger, coleccionar, clasificar y remitir a Veracruz, los papeles del señor del Paso y Troncoso. Además, como lo solicité, me comisionó también para que continuara mis investigaciones históricas en los archivos de España. Pues bien: hasta esta fecha no he recibido un centavo de sueldo. ¿Negligencia? ¿Dificultad? ¿Otra cosa? Chi lo sa. Ello es que la inquietud parece ser conmigo una querida apasionada. No me abandona. Anteayer puse dos cables con sendos gritos de náufrago. Mientras me contestan braceo para no ahogarme.

No me imaginaba yo este abandono, porque, en lugar de tropezar, a mi llegada a México, malas voluntades, hallé buena acogida en los altos círculos, y entre los amigos y compañeros. Muy gentil el Ministro de Educación, doctor Puig; muy afable Pérez Taylor, el jefe de Bellas Artes. Alberto Pani, muy cariñoso y complaciente (me invitó a comer en su casa); el Ministro de Relaciones, afectuoso y dispuesto a servirme (obra, seguramente, de nuestro fraternal Genaro Estrada); y hasta una persona que yo no conocía, el Lic. Don Gilberto Valenzuela, lleno de simpatía y generoso. El ambiente me pareció halagador, y logré aprovecharlo. Pedí la comisión, discretamente, sin gastos para el Gobierno, sólo el traslado a Madrid, de mi sueldo como Secretario del Museo, puesto que me dieron tan pronto como llegué, a modo de provisional gana-pan. Mis gastos de viaje me los regaló un rico y buen amigo mío, español: Don Adolfo Prieto. Y así salí de la tierra, tan amada de lejos, tan maltratadora y áspera de cerca. Si ves a Manuel Ponce, dile que te enseñe el párrafo de mi carta que se refiere a la atmósfera moral de México. Ahí le digo cómo las pasiones que antes nos provocaban a la lucha, y eran enemigos de nuestro tamaño, o más grandes, ahora se achicaron, y son duendecillos inconsistentes, gnomos subterráneos, que, a nuestro paso, preparan el hundimiento del camino para que caigamos sin conocer a quién debemos la caída. El combate es silencioso, entre los que valen y no valen, entre los aptos y los ineptos. Siempre ha sido así. Solamente que antes solían ganar los útiles, los preparados, los cultos. Y ahora, no. Vencen los otros, disfrazados con la remendada y colorida capa de mendigo de los vocablos de moda: redención, reivindicación... Antes, el odio y el amor eran reales. Ahora, son falsos. Y las invocaciones suenan 
a vacío. Es decir, no; suenan a egoísmo, a ambición personal, a medro sórdido. Lo que se quiere es vivir ampliamente, perezosamente, sin chirimbolas de estudios ni especialidades. Encumbramiento, dinero, lujo, desenfado. ¿Y quién dijo miedo? Con la fuerza de la despreocupación y el quemeimportismo se han aflojado los lazos del deber. Todo eso es muy postguerra. En México lo agrava el desequilibrio secular: nueve millones de indios, movidos y removidos brutalmente por tres millones de mestizos. Los indios son el rencor impotente, la inadaptación asombrada, el pesado fardo de la miseria. Los mestizos son la audacia sin freno, la inquietud sin ideal, el sensualismo sin refinamiento. En las manos del cura, el indio es superstición. En las manos del general, es trinchera. Su carne sirve para todo. Es aprovechable para todos los engaños, para el político principalmente. En la tribuna parlamentaria no hay nada más declamatorio que invocar al indio. ¿Qué mina tan explotable para los seudo redentores!

¿Pero por qué te hablo de estas cosas que tú sabes y piensas mejor que yo? Perdóname. Se me fue la mano. Es que quería darte mi última impresión de conjunto.

Ahora bien. Hay incrustados en esta barahúnda núcleos mínimos de inteligencia preparada y de virtud civil. Hay hombres brújulas en esta desorientación. Hay jóvenes que se sustraen al contagio. De su resistencia depende la salvación. Yo creo que resistirán. Entre las gentes de gobierno hay pensamientos claros y caracteres rectos. La esperanza no se puede perder. Esta descomposición colectiva es, acaso, un síntoma de vigor popular. Es, quizá, como la fiebre: un deseo del organismo de eliminar toxinas, de purificarse. En todo caso, es vida. Es bueno observarla serenamente.

Aquí tienes, mi hermano Alfonso, un esquema de mis impresiones mexicanas.

Hablemos de lo tuyo. Sí. Noté y comprobé la enemistad que hacia ti sienten personas que no ha mucho se decían tus amigos. Inútil decirte - porque me conoces y estás seguro de mí- cuál fue mi papel. Defenderte, no únicamente con andar ciego sino con justas y tranquilas razones. Creo que estos aborrecimientos artificiales están engendrados por el mismo estado espiritual de todo el país. La malevolencia y la calumnia han substituido al mauser y la ametralladora, aunque las cuatro armas puedan funcionar simultáneamente. No debes hacer caso. Estas pirotecnias sentimentales de la ofensa y el agravio son las más efímeras: el más leve soplo de aire las desvanece y apaga. Tu energía cordial y la elevación de tu talento sobrevivirán, sin mengua, a esos cohetes inofensivos, si bien molestos y malolientes.

Ahora, te diré: he buscado en vano los papeles del Sr. del Paso y Troncoso. La repentina muerte de Pancho Icaza - noticia que 
recibí al llegar a La Habana- me da en qué pensar acerca del paradero de los dichos papeles. ¿Habrán quedado en poder de la familia que ahora está en México gestionando - según sé- una pensión? Yo indago, husmeo, atisbo; pero nunca ofenderé la memoria de un amigo a quien tendí, sinceramente, la mano. María Enriqueta y Carlos Pereira han elevado memoriales al Gobierno de México, semidenunciando irregularidades y substracciones. Dime confidencialmente, si algo sabes. Guardaré clausurada reserva.

Tan pronto como anden medianamente estos títeres de erudición y documentación que traigo entre manos, iré a buscarte a $\mathrm{Pa}$ rís. - Oh sí, yo volveré, París divino! - y pasaré contigo unas semanas. Encantado de tu invitación que acepto con el alma.

Ya te di la lata. Discúlpame el desahogo. Es una prueba de mi cariño. Saluda afectuosamente a Manuelita. Besa a Alfonsito. Recibe mis abrazos

Luis

Esta larga carta, de quejas y reflexiones, además de dejar testimonio de las lamentables circunstancias en que se desenvuelve la vida de Urbina, recoge su apreciación del mundo oficial de la ciudad de México y de las condiciones de marginación e injusticia de los indígenas, explotados y manipulados por quienes son "la audacia sin freno, la inquietud sin ideal, el sensualismo sin refinamiento". Lamentablemente está perdida la mayor parte de la correspondencia de Urbina y sería interesante poder leer su carta a Manuel M. Ponce sobre "la atmósfera moral de México". El exilio de Luis G. Urbina debió ser muy doloroso para él, pero al mismo tiempo lo mantenía distante de su tierra "tan amada de lejos, tan maltratadora y áspera de cerca".

El primero de enero de 1926, Urbina fue designado Director de la Comisión "Francisco del Paso y Troncoso", y debió viajar a Sevilla para trabajar directamente en el Archivo de Indias. Desde esta ciudad escribió a Reyes en París:

Mi querido hermano Alfonso:

Sevilla, 28 de abril de 1926

Me cayeron tus tres sentidas líneas, sobre una mesa polvorienta del famoso Archivo de Indias. Estoy aquí trabajando desde hace más de dos meses; entre inquietudes de hoy y papeles de ayer. Tú, que tan completamente conoces esta clase de labores, comprenderás cuánto me voy hundiendo en la vida de antaño y olvidando mi propia actualidad. Esto es un mar y estoy con el agua en las narices. Hay primores de hechos muertos y he de esforzarme en resucitarlos y en echarlos a andar. De algo nos ha de servir la costumbre 
de la visión lejana. El calor de Sevilla me va a mandar muy pronto a Madrid. El aire ya comienza a quemar. Y la temperatura excesiva recrudece mis achaques que no me dejan a sol ni a sombra, pero que se atenúan con la tibieza del clima. Espero que el mayo madrileño me será propicio. De allí, en llegando, te volveré a escribir. No pasará una semana.

Porque has de saber que no es preciso que llenes mi silencio. Sin literatura - valga la imagen por lo exacta - mi silencio ha estado siempre lleno de tu recuerdo. No olvido - no olvidaré- ni tu cariño ni tu bondad.

¿Qué me ha pasado? Entre otras cosas, cierto pudor, cierto temor de seguir contándote mis dificultades mínimas - para mí máximas - con el mundo positivo del dinero. Una sola frase te bastará para comprenderlas. Anoche - ¡hasta anoche! - recibí dos noticias halagadoras: que autorizan el pago de mis sueldos como encargado de la "Comisión del Paso y Troncoso" y que nuestro excelente Genaro Estrada me da otra, con un pequeño subsidio más. En total 21 pesos mexicanos diarios. La salvación. La gloria. Pero que si llega un poco más tarde, me encuentra, de fijo, en agonía. Guatro meses de angustias, consoladas y olvidadas por el fraternal González Martínez. Varias veces pensé comunicarte estas ínfimas penas, de las que me han medio salvado los artículos del Universal, cuyo producto, como sabes, comparto con Lucesita y los auxilios de González Martínez. Varias veces pensé también que esta constante situación mía iba a mortificarte. Y así se pasaron los días. Pero acaso no ha pasado uno solo sin que mi memoria dejara de presentarme tu afable sonrisa y tus ojos amables. Estoy escribiendo el informe de mis investigaciones. En mi próxima carta te hablaré de él. Se me ha removido la enfermedad lírica: he pergeñado versos. Escríbeme tú a Fernán González 7, a donde siempre. Camila, que te recuerda a cada rato, te manda saludar.

Dile a Manuelita que le mando muy afectuosas expresiones. Besa a Alfonsito. Recibe un abrazo muy largo de tu hermano

Luis

La visita, o visitas, de Luis G. Urbina al Archivo de Indias en Sevilla, las hacía con las limitaciones de sus propios recursos, pues no le llegaban los fondos de México. Su largo silencio de casi medio año (su carta anterior es del 22 de octubre de 1925) se explica porque no quería repetirle a Reyes su problema de pobreza y limitaciones, que como se ve seguía resolviendo la generosidad de Enrique González Martínez. "Se me ha removido la enfermedad lírica: he pergeñado versos", dice Urbina, porque después de Los últimos pájaros había decidido no escribir más poesía. 
Este material se publicó en México en edición póstuma de 1941, con prólogo de Alfonso Reyes (quien había concluido su trabajo diplomático en 1939), doce años después de que Luis G. Urbina integrara esos poemas para su edición, el año de $1929^{13}$.

Dos cartas más envió Urbina a Reyes ese año de 1926:

Mi muy querido Alfonso:

Ávila, agosto 16 de 1926

Te mando con estas líneas unas cuartillas, copia de mi crónica escrita para "El Universal" de México. Son un fragmento nada más y forman parte de una serie que he titulado: "Libros de México bajo árboles de Castilla". Fue aquí, sin un libro, sin un pequeño diccionario, sin bagaje alguno, donde pensé e intenté un esbozo de crítica impresionista de tu 'Pausa". Todo faltará en mi articulillo periodístico, menos mi admiración y mi cariño por ti. He deseado que lo vieras antes de que se publique. Escribirlo no; copiarlo es un homenaje a tu talento. Mis felicitaciones. Mis aplausos. Perdóname en gracia de mi sana atención.

Me supongo que estarás ya compartiendo tu vida espiritual con Alfredo Gómez de la Vega. Este intrépido e inteligente amigo nuestro ha hecho una última temporada en Madrid realmente gloriosa. Y quiere mostrar sus timbres y lucir sus conquistas, en una visita a nuestro México. Me parece muy bien pensado, aunque acaso... la crisis social no sea propicia a sus proyectos. Yo sé bien que le ayudarás, porque a generoso y noble no te gana nadie. Este muchacho merece tu protección. Mil gracias por ella.

Y nada más, sino que disculpes mi osadía por haber intentado hacer un boceto de crítica de tu delicado libro "Pausa". Repito la súplica.

Saludos a Manuelita. Besos a Alfonsito.

Un abrazo de tu hermano.

Luis

Mi inolvidable Alfonso:

Madrid, septiembre 2 de 1926

No sé si recordarás a Pablo, el hermano de Camila, a quien verías en tus visitas al Museo del Prado, de donde es uno de los porteros. Se llama Pablo Ruiz, es un muchacho excelente, que, aunque sin cultura completa, tiene un notable ahínco de ver, de saber y de educar su espíritu. Ya está bastante enterado de cosas de arte plástico. Ahora va a París, aprovechando sus vacaciones, en busca del

${ }^{13}$ LuIs G. URBINA, El cancionero de la noche serena [Imprenta Universitaria], México, 1941. 
Louvre, del Luxemburgo, y de los aspectos estéticos de la gran ciudad. Te lleva un abrazo mío, el de siempre, el fraternal y cordialísimo.

Te recomiendo al chico, por si necesitare de tu ayuda. Te anticipo las gracias.

Recibí tu efusiva carta. Al leerla, se me humedecieron los ojos, el bueno eres tú, hermano mío.

He leído "Reloj de sol"'. Tiene páginas admirables que has hecho bien en recoger. Ahí te va otra felicitación.

Y dime: ¿dónde anda Gómez de la Vega? ¿qué hace? ¿cuándo marchará a México? He perdido todo rastro de eso.

Saluda a tu Manuelita. Besos a tu Alfonsito. No olvides a tu viejecito.

Luis

En estas dos cartas nada más queda mención a los libros de Reyes. Urbina, aunque escribía de nuevo poesía, ya no publicó ningún libro después de 1924. Alfredo Gómez de la Vega, el notable actor mexicano, quien hizo amistad con Luis G. Urbina desde su arribo a España en 1916, se encontraba en 1926 en la cima de su carrera, iniciada en Madrid y consolidada después en México.

Alfonso Reyes termina su trabajo diplomático en París y se embarca con rumbo a México en marzo de 1927. En abril es designado ministro en la República Argentina, y parte a Buenos Aires, vía Nueva York, a principios de junio. En el barco recibe noticia de su designación como embajador en Argentina. Aquí permanecerá hasta el mes de abril de 1930, para trasladarse como embajador a Río de Janeiro. Las dos últimas cartas de Urbina a Reyes conservadas en el archivo de éste están dirigidas desde Madrid a Buenos Aires:

Mi inolvidable Alfonso:

Madrid, julio 16 de 1928

Hace más de un mes que nuestro amigo - ya por ser tuyo lo es mío- el doctor Juan J. Bada me dio tu carta. Él acaso te escriba diciéndote lo que ha logrado en su empresa. Yo he puesto mi voluntad que es mucha pero que puede muy poco. Algunas veces ha venido a verme Bada. Es simpático, inteligente, de vivacidad juvenil. Me parece bueno. Lo será puesto que hizo buenas migas contigo. Ha venido a visitarme tres o cuatro veces a mi Tebaida. Porque has de saber que ahora vivo en el extra-radio de Madrid, a un lado de la carretera de Aragón, un barrio envuelto en polvo y sol -como la gloria huguiana- y en el que viven muchos obreros y al- 
gunos gitanos. Como telón de fondo, en un desmedrado jardincito, se ve la fachada-galería del Cementerio de la Almudena. El hotelito, hecho con cuatro ladrillos y tres palos, se llama: Villa Camila. De Camila es. Guarda sus escrituras; cuida sus gallinas y sus flores, y hasta creo que se da sus humillos de propietaria. A él ha llevado a su familia - a su madre y a sus hermanos solteros- y a mí que, aunque advenedizo, busco sombra familiar. No sé que será mañana de mí. Ojalá que la suerte me dejara en este rincón de olvido. Aquí seguiré yo la rumia espiritual. Dios lo haga. También el polvo se cansa de ser barrido.

$\mathrm{Y}$ aquí como en dondequiera que esté yo, mi pensamiento va ti [sic], y mi recuerdo te sigue cariñosamente. Y aunque tu existencia es agitada, múltiple, brillante, estoy seguro de ocupar un lugarcito en tu corazón generoso.

Cada vez que puedas, ponme dos líneas que me hagan saber de ti. Saluda con todo afecto a Manuelita y besa a tu niñote.

Un abrazo de tu viejecito.

Luis

Dirección: Ventas del Espíritu Santo. Barrio del Carmen. Calle de Martín Freg, 18, Madrid.

Casi un año después de esta carta, en abril de 1929, falleció en México doña Luz Roseta de Urbina, esposa del poeta, a quien éste visitó sólo en tres ocasiones, en 1917, 1921 y 1925, desde que se trasladó a España en 1916. Todo ese tiempo, la esposa de Urbina recibió fondos que le situaba $E l$ Universal, donde él publicaba sus crónicas de Madrid. Ahora, en 1928 y gracias a la desahogada situación económica que le proporcionó el puesto de director de la Comisión "Del Paso y Troncoso", Urbina adquirió una modesta y pequeña casa en las afueras de Madrid, a nombre de su compañera Camila Ruiz Penalver.

La última carta es del 5 de febrero de 1930. Urbina había mandado semanas antes su última colaboración, publicada el día 9 de ese mes de febrero, al periódico El Universal de México. De la carta se desprende que Urbina continuaba trabajando en la Comisión "Del Paso y Troncoso":

Mi querido hermano Alfonso: Haces bien en pensar que la confianza que tenemos en nuestro cariño está por encima de toda urbana cortesía y por debajo de todo prolongado silencio. Tú y yo sabemos bien cuán honda es la raíz de esta amistad que esmeradamente cultivamos desde mucho tiempo ha. La planta, conforme pasan los años está más frondosa y más florecida de ternura. ¡Como que la hemos regado más de una vez con lágrimas íntimas, en 
horas de confidencias y pesares! Estás en mi corazón. Vives en mi recuerdo. Y cuando la vida clava las uñas en mi suerte, evoco tu alma suave y piadosa y no me siento tan triste ni tan solo. Pero es, mi querido Alfonso, que estamos en distintos planos, y que tu existencia se atomiza en ráfagas apasionadas y brillantes; y yo, desde mi rincón de sombra y olvido, temo echar soplos de melancolía y perturbar, por un instante, el polvo de oro que bulle en tu cinta de sol.

Sin embargo, te escribí, desde Sevilla, en el pasado octubre. $\mathrm{Tu}$ carta que acabo de recibir, me da la sospecha de que no recibiste mis líneas, las cuales, por lo demás, no eran sino simple expresión de mi viejo sentimiento.

Has adivinado. No soy feliz; pero si la tranquila contemplación del mundo, si el apaciguamiento del espíritu, nos acercan a una posible dicha, en camino estoy de llegar al término. Pasó la época de los ciclones. De cuando en cuando, un poco de mar de fondo, y nada más. He logrado el milagro de sacarme fuera de mí mismo, y verme en perspectiva. El espectáculo me entretiene y me hace pensar en las ciegas fuerzas de mi destino inexorable.

Lo malo es que la edad y los achaques están deshaciendo mi barca. Me siento con pocas ganas para seguir en la faena. Mas como hay que vivir no queda otro remedio que orzar para que ayude un poco el viento.

Ahora mismo me levanto de un periodo de dolencias y desalientos. Espero volver dentro de unos días a mis labores del Archivo de Indias, si es que me dejan la comisión de investigador. ¡Ojalá que sí!

He leído con emoción tu cuento: Fuga de Navidad. Está preciosamente hecho. Es una página muy vivida. ¿Qué más has hecho? Cuando puedas, chárlame de eso.

Te he quitado más tiempo del que yo pensaba. Dispénsame. Y cree que la lámpara sigue ardiendo, y no se extinguirá sino con la muerte.

Saluda a Manuelita. Besa a Alfonsito. Para ti mi abrazo de hermano.

Luis

En 1930 Urbina tenía 66 años, estaba enfermo y cansado, sin fuerzas para continuar luchando, y le quedaban casi cinco años de vida. Reyes, en cambio, tenía 41 años y todavía faltaban nueve por terminar su trabajo diplomático, regresar a México, y vivir sus últimos veinte años con una producción muy extensa en todos los géneros que cultivó. Es posible que Urbina haya optado por el silencio, para no comunicar al amigo las penalidades de su vida en declive.

A Genaro Estrada debemos una imagen de los últimos años 
de Luis G. Urbina, al que visitó en Madrid en su casa de Martín Freg, 18. "Cuando llegué a España, en 1932, ya Luis G. Urbina ofrecía a simple vista todo el aspecto de un hombre vencido por los achaques y entristecido por la vida"'14. Trabajaba como podía para cumplir su labor de rescate de documentos en el Archivo de Indias y se mantenía aislado, al grado que mucha gente creía que había regresado a México.

Poco antes de morir, Urbina contrajo matrimonio con Camila Ruiz, por insinuación y sugerencia de Genaro Estrada, quien además intentó convencerlo de regresar a México.

No quería regresar, y casi siempre eludía este tema, cuando yo le proponía la vuelta a México. Quejábase de que estaba olvidado, de que ya nadie le escribía, de sus decepciones con antiguos amigos, de que aquí no tendría recursos para subsistir . . asegurándome que la ciudad de México - ;su vieja ciudad de México que él tanto amaba! - no cuadraba a su actual temperamento.

Genaro Estrada menciona el tema de las memorias, nunca escritas por Urbina. Veinte años antes, el poeta había escrito a Alfonso Reyes: "Porque no quiero dejar de decir mi palabra, la que ha de revelar cómo un hombre, más o menos corriente, vio la vida de los demás en relación con la suya propia' (carta de octubre 20 de 1914). En 1934, según el testimonio de Estrada, no quería escribir porque "las memorias sirven para conocer a los grandes hombres o a los vanidosos que gustan de exhibir su egoísmo y sus pequeños chismes'”. Aunque añadía: “Sí, sí, con mis memorias se podría reconstruir un México peculiar que yo conocí muy bien'.

Luis G. Urbina murió a las tres de la tarde del día 18 de noviembre de 1934. Las autoridades mexicanas dispusieron el traslado a México del cadáver, que llegó a Veracruz en el vapor " $\mathrm{Ha}$ bana" el 11 de diciembre. Ese día se rindieron honores al poeta desaparecido y el día siguiente llegó el féretro a la ciudad de México. Los restos se depositaron en la Rotonda de los Hombres Ilustres el 13 de diciembre de 1934.

El 17 de diciembre de 1934 la viuda de Urbina escribió a Alfonso Reyes en Río de Janeiro; don Alfonso había regresado en

${ }^{14}$ Genaro Estrada, "Luis G. Urbina en España y sus últimos días", Obras. Poesía, narrativa, crítica, FCE, México, 1983, pp. 380-385. 
esos días de México, donde murió su madre. Camila Ruiz viuda de Urbina le expresa sus sentimientos por esa pérdida y le habla del poeta muerto: "a usted era uno de los que más quería en el mundo (lo sé bien), supo su llegada a México dos días antes y dijo, tengo que escribir a mi Alfonsito. Pobre, qué poco duró".

La siguiente carta es del 19 de febrero de 1935 y entre otras cosas le dice a Reyes:

D. Alfonso, entre los papeles del pobre Viejecito hay dos sobres para que se los entreguemos a usted, yo sé es algo de su vida íntima, pero no he querido ni que nadie lo vea ni que nadie se entere, así que usted dirá cómo se los mando...

Una tercera carta es del 11 de febrero de 1939:

Mi estimado y bueno Don Alfonso: Recibí su carta atenta y cariñosa del nueve de enero, sintiendo no haber recibido la anterior; quedo tranquila al saber que tiene en su poder los sobres que le mandé de nuestro amado Viejecito (Q.E.P.D.), ya sé cuánto cariño guardará usted a todo lo suyo./ Mi nunca bien llorado Luisito me habló de usted en muchas ocasiones, con verdadero cariño de padre le quería mucho; yo hoy un poco más tranquila y recordando las conversaciones tenidas con él en la intimidad. Alguna vez me dijo que si él por casualidad moría sin testar, que siempre me aconsejara de usted, y teniendo en cuenta este deseo suyo y sabiendo usted como yo su amor a los libros, quisiera me orientara qué sería bueno hacer con ellos, porque mientras yo viva, todo lo suyo lo guardaré como una reliquia, pero no quisiera morir sin arreglar esto, sentiría mucho pasara a manos que no lo supieran apreciar, así que lo dejo al buen sentido de usted...

De los dos sobres mencionados por la viuda de Urbina y que dice ya recibió Alfonso Reyes en Río, no se ha podido saber su contenido; no se trata de sus memorias, como se verá más adelante, pero por lo que afirma la viuda, se trata de textos personales de Urbina, que quizá ella misma no conoció, si esos sobres estaban y se mantuvieron cerrados ${ }^{15}$. En la misma carta del 11 de febrero de 1936, continúa Camila Ruiz viuda de Urbina:

15 “'Todavía me alcanzó en Sudamérica su mensaje póstumo: papeles que no interesan a la posteridad" (Alfonso ReYes, "Recordación de Urbina", p. 278). 
en ésta (su casa) todo está como él lo tenía, no se figura la pena que me da tocar sus cosas, me parece que así lo veo, y oigo sus pasitos, menudos y silenciosos; pero al mismo tiempo comprendo que así no pueden quedar sus cosas; le sorpendió la muerte cuando se decidió a escribir sus memorias, no obstante dejó unas cuartillas hechas, ha sido una lástima que no pudiera terminar pues tiene cosas muy curiosas, y otras, que él contaba con su gracia propia que usted sabe él tenía, fue una lástima que no le diera tiempo hacer más pero en esto se hizo, y válgame la palabra que él empleaba y que siempre le producía risa, se hizo pendejo, no olvidó que usted en todas sus cartas se lo rogaba y yo también se lo decía pero en esto no nos escuchó. Yo quisiera si esto se publicara, que fuera usted el que se entendiera con todo esto, pues usted es el que sabrá dar su verdadero sentido a estos escritos, no he dicho a nadie nada, por tener puesta la confianza en usted y estar segura que me dará la solución de todo esto.

Finalmente se sabe ahora que Luis G. Urbina dejó sus memorias, aunque incompletas. Quizá escuchó el consejo de Genaro Estrada, que reiteró el pedido de Alfonso Reyes en sus cartas. Es posible que estas memorias, si como parece Urbina empezó a escribirlas poco antes de morir, sean muy breves, pero de todas formas tienen valor para la historia de nuestras letras. Alfonso Reyes contestó desde Río a la viuda de Urbina:

Ríojaneiro, 3 de marzo de 1936

Ante todo, querida Camila, le agradezco el caso que hace de mi recuerdo y la confianza que Ud. pone en mi amor al Viejecito inolvidable. Su carta del 11 de febrero último ha llegado a mis manos con la buena nueva de que nuestro Luis dejó algunas cuartillas de memorias, las cuales, por pocas que sean, sé yo que contendrán un valor inmenso.

Me habla usted, entre otras cosas, del destino que habría que dar a los libros de Luis, o mejor que "dar", "prever", para en que caso de muerte de usted, ocasión que espero en Dios esté muy lejana. Claro es que mientras usted viva, y sea por muchos años, en ninguna parte estarán mejor custodiados que entre sus manos cariñosas. Pero, ya que usted quiere tomar providencias para el porvenir, yo realmente creo que sería lo más puesto en razón el dejar tales libros como legado, para cuando usted falte, a la Biblioteca Nacional de México, en nombre y en memoria del poeta Urbina que algún tiempo fue su Director. Yo creo que esto a él le hubiera agradado. Y no le hablo de dejar tales libros a los amigos, porque nadie sabe quién estará vivo para entonces, que si no, yo me apresuraría 
a ofrecerle incorporarlos a la inmensa familia de libros que tengo yo en México, en mi casa, bajo la custodia de mi hijo, y que ocupa cinco grandes salas con estantes bien apretados.

Si a Ud. le agrada, a mí me entusiasma la idea de recoger y publicar cuidadosamente, por cuenta mía y en beneficio de Ud. y en la forma y manera que a Ud. más le plazca, esas cuartillas inéditas de memorias, así como cuantos papeles inéditos de carácter publicable hayan quedado por ahí. No tiene más que mandármelos en un paquete protegido con cartones y bien certificado, que yo los cuidaré y trataré como cosa santa. Ud. ya sabe el empeño que yo tenía en que ese hombre de alma ejemplar nos dejara la lección de su vida y sus memorias completas. Pero, en verdad, "se hizo pendejo". . . En fin, algo es algo, y aun mucho puesto que viene de él.

Manuelita volvió ya de México para compartir conmigo esta soledad en que nos tiene la ausencia del hijo único. Me consuela el haber recibido las mejores noticias de mi Alfonsito, que está estudiando muy bien y tomando muy en serio la vida. Ella me encarga saludos y recuerdos para Ud. Y yo le mando todo mi afecto, redoblado y multiplicado con aquel recuerdo que nos une. Muy suyo

A.R. Laranjeiras 397

El 31 de marzo de ese mismo año, la viuda de Urbina escribió de nuevo a Alfonso Reyes y hace mención de los textos que dejó el poeta: "D. Alfonso, de las cuartillas que nuestro amado Luisito dejó escritas, las recogeré y se las mandaré, así como algunos datos de los últimos años, y desde que conocí al Viejecito, y de mis familiares". En esta misma carta la viuda dice que tiene "el primer libro que hizo, se titula La última serenata (poema, 1887), no sé si usted lo conocerá, está de su puño dedicado a su papá cuando tenía 14 años. Es un librito chiquito". Este poema está recogido en Ingenuas (1902), con la mención al final "Publicado en Versos, 1890)"'16. En la edad que menciona la viuda hay un error, pues en 1887 Urbina tenía 23 años, y si ella estuviera en la creencia de que él había nacido en 1867, como el propio poeta decía, la edad sería de 20 años. De todas formas, si ésta es una edición separada del poema no está incluida en la bibliografía de Luis G. Urbina. Hay otra referencia curiosa en la misma carta, con relación a un libro de Urbina, depositado en la Casa Ciap "hará como cuatro o cinco años", pero que él mismo no quiso

${ }^{16}$ Luis G. Urbina, Poesías completas, ed. y pról. Antonio Castro Leal, Porrúa, México, 1946, t. 1, pp. 60-73. 
que se editara. Esta editorial estaba cerrada judicialmente y no se podía recoger el material. Sin embargo, la viuda añade que este libro lo iba a publicar la Casa Araluce, de Barcelona. Salvo que se tratara del Cancionero de la noche serena, para el cual se sabe que Urbina no encontró editor, no es posible precisar de qué libro se trata.

La siguiente carta de Camila Ruiz viuda de Urbina a Alfonso Reyes es del 10 de enero de 1938, en plena guerra civil. Está dedicada a plantear el problema del pago de la pensión que le adeuda el gobierno mexicano, pero menciona su intención de viajar a México, vía Barcelona y París, "propósito que tengo formado desde hace algún tiempo, para encontrarme más cerca de mi viejito y así consolarme de la soledad y tristes recuerdos en que estoy sumida". También informa sobre el destino de los libros y papeles de Urbina:

... con fecha 20 de noviembre último, entregué en nuestra embajada la Biblioteca, para hacerla seguir en su día a la Biblioteca Nacional de México. Ya escribí al Director dándole cuenta de esta donación. Cuantos papeles le ofrecí del viejito, se los mandaré o los llevaré personalmente a ésa, no habiéndolo hecho antes por temor a pérdidas que serían lamentables, dada la anormalidad de las circunstancias. No olvido este ofrecimiento que cumpliré exactamente.

Esta carta, que pudo enviarse directamente a México, pues la viuda de Urbina menciona haber recibido la de Reyes del 20 de diciembre de 1937, en la que posiblemente recibió informe de éste de su regreso a Méxio al concluir su misión diplomática en Buenos Aires, tuvo respuesta desde la ciudad de México el 15 de febrero de ese año de 1938:

Mi buena amiga:

He leído con todo interés y emoción su grata carta del 10 de enero, y ya me imagino la penosa situación que estará usted atravesando entre la tragedia de España y el retardo de mi Gobierno para despachar el asunto de sus pensiones. Voy a ponerme en contacto con algunos amigos del departamento respectivo para ver si despachan su asunto lo más pronto posible.

Quedo en espera de los papeles del viejecito que usted me anuncia. Tome todas las precauciones del caso pues tanto para usted como para mí y para incontables personas, esos papeles son verdaderas joyas. 
Reciba los más cariñosos saludos de mi familia y cuente siempre con su viejo amigo.

Lic. Alfonso Reyes

Córdoba núm. 95

Ese mismo día 15 de febrero Alfonso Reyes se comunicó con Rafael Cabrera, su amigo de los tiempos del Ateneo de la Juventud, para tratar el problema de la pensión; poco después sale de México en misión especial a Río de Janeiro, de la que regresa en enero del siguiente año. En diciembre de 1939 ya está en Lisboa la viuda de Urbina y desde ahí escribe a Reyes. Llega a México y habita en el número 66 de la Avenida 2, en San Pedro de los Pinos.

El 3 de julio de 1940, seguramente atendiendo la solicitud de la viuda de Urbina, Alfonso Reyes dirigió carta al ministro en México de la República Dominicana, Teódulo Pina Chevalier:

Señor Ministro y muy distinguido amigo:

A la muerte de nuestro poeta Luis G. Urbina, sus últimos papeles y libros quedaron en manos de su viuda, doña Camila Ruiz de Urbina, actualmente entre nosotros; y yo quedé encargado de recogerlos para consagrarles toda mi piedad y mi cariño y ver de que no se nos pierdan. La viuda me dice que depositó todo esto, al venir la catástrofe española, en nuestra Embajada en aquel país. Todo se encuentra, pues, actualmente en la Legación Dominicana de Madrid. Escribo a usted en nombre de la señora de Urbina y en el propio para rogarle que interponga sus buenos oficios a fin de que recobremos tan valiosas reliquias. Tal vez a través del Gobierno Dominicano sería fácil obtener que todo ello le fuera remitido a usted y yo lo recogería de sus manos. Dígame usted qué resuelve sobre el caso y de antemano acepte mi profundo agradecimiento.

Con mis mejores respetos para la familia, quedo su cordial amigo y atento s.s.

Alfonso Reyes

Al parecer no hubo respuesta a esta petición. Dos años más tarde, el Subsecretario de Relaciones Exteriores, Jaime Torres Bodet, se dirigió al Ministro de México en Ciudad Trujillo, solicitándole pidiera al gobierno de ese país retirar de los archivos de la extinta Embajada de México en España, que habían quedado a cargo de la representación Diplomática de la República Dominicana en Madrid, tres paquetes con documentos del poeta mexicano Luis G. Urbina, para entregarlos a su viuda. Este comuni- 
cado se envió con copia al Ministro de México en Lisboa, y a la viuda. Seis meses más tarde, el 22 de septiembre, el Ministro de Lisboa, J.M. Álvarez del Castillo, envió al Secretario de Relaciones Exteriores los tres paquetes que supuestamente contenían los documentos de Luis G. Urbina. La viuda del poeta recibió el 21 de diciembre de ese año de 1942, y firmó el recibo correspondiente, dos libros y dos paquetes que pertenecieron a su esposo, con la mención: "dichos libros contienen recortes de periódicos y los bultos documentos"'. Sin embargo, esto no era lo que esperaba recibir la viuda, pues al día siguiente, 22 de diciembre, se envió este mensaje a Lisboa: "Recibiéronse tres paquetes con documentos Urbina STOP Su Viuda indicamos faltan manuscritos principales los que probablemente encuéntranse en tres paquetes grandes STOP Ruégole investigar informando esta vía. Relaciones"'.

Dos meses después, el 15 de febrero de 1943, el Cónsul de México en Giudad Trujillo transcribe un comunicado del Secretario de Relaciones Exteriores de la República Dominicana, de fecha 10 de ese mes y año, ratificando el envío de los tres paquetes por conducto de la Legación de México en Lisboa. Aunque no se aclara si se trata de los tres paquetes con "manuscritos principales", por la referencia a la ratificación del envío debe entenderse que se trata de los tres paquetes originalmente enviados en el mes de septiembre del año anterior. En confirmación de lo anterior el Ministro Álvarez del Castillo informa el 14 de abril de 1943: "De viva voz Ministro Dominicano Madrid díceme no haber encontrado manuscritos refirióse suyo 52747 habiéndosele encarecido repita cuidadosamente búsqueda" 17 .

De todo lo anterior se concluye que libros y documentos no pudieron rescatarse de la Embajada Dominicana en Madrid. De los documentos al menos se sabe que incluían las memorias inconclusas de Urbina y otros textos personales. De los libros queda el testimonio de Genaro Estrada, incluido en su artículo sobre los últimos días de Urbina en Madrid:

La casa de Urbina era un juguete: un saloncillo minúsculo, un comedor algo más amplio, las habitaciones de Camila y de sus parientes, la diminuta alcoba del poeta, en donde éste dormía en un angosto lecho con cubierta de terciopelo rojo oscuro y la biblioteca:

17 Toda esta información se encuentra en el expediente de Luis G. Urbina, en la Secretaría de Relaciones Exteriores. 
aquí estaban ocupando hasta la línea del techo, sus libros de siempre; autores españoles, franceses, mexicanos... ${ }^{18}$

Sin embargo, Ernesto Mejía Sánchez, en su trabajo sobre Urbina con motivo del centenario de su nacimiento, afirma que "los libros llegaron al fin a México, pero, por causas que se ignoran, no a su hogar definitivo" 19 . En el expediente de Urbina en la Secretaría de Relaciones Exteriores se encuentra un memorandum sin fecha, firmado por el licenciado Manuel López Cleres, en el que se hace referencia a la pensión de la viuda de Urbina y se dice que la señora "cedió gratuitamente a la Universidad Nacional la biblioteca del ilustre desaparecido, conteniendo numerosos volúmenes y documentos de valor e interés para la Nación".

En el Fondo Especial de la Biblioteca Nacional no fue posible encontrar la documentación y libros de Luis G. Urbina.

Alfonso Rangel Guerra

18 Véase nota 14.

${ }^{19}$ ERnesto Mejía SÁnchez, "Urbina y la Biblioteca Nacional", Boletín de la Biblioteca Nacional, segunda época, t. 15, núms. 1-2, 1964, 61-74. 